\title{
Historia de la imagen de Dios
}

\section{Mrto, FILOSOfÍA, REVElación.}

La filosofía tuvo su prehistoria, que es el mito. La aspiración de la filosofía fue siempre "suplantar" al mito y sus métodos 1 , pero Grecia corrió todo su ciclo cultural sin poderse despegar de la Natura. La filosofía griega vivía inmersa en la Natura, como un feto en su matriz ${ }^{2}$. Estaba tan condicionada por el prejuicio naturalista como el hombre que trabajaba con el mito. En lugar de suplantar al mito, lo transformó y continuó. Siguió imperando en el mundo la idea de la causalidad formal, la genetación. La filosofía se convirtió en un capítulo $D e$ generatione et corruptione, en una dialéctica. En este sentido, el filósofo era inferior al hombre que creaba el mito, puesto que este nunca perdía su libertad personal y profesional, mientras que el filósofo se veía condenado a convertir la sociedad humana en un inmenso rebaño de animales dotados de razón, pero privados de libertad auténtica. Al parecer, se llegaba muy lejos con la dialéctica, puesto que los hombres quedaban encerrados en la ciudad de los dioses, para construir una Cosmópolis: eran ya iguales a los dioses, se alcanzaba la apoteosis ambicionada. Pero era sólo una apariencia: en realidad, los dioses quedaban rebajados a la categoría de "divinos muñecos": tampoco ellos eran libres; tampoco ellos eran espíritus. La única divinidad suprema era la Anánke, la Natura ciega, la gran Inteligencia o la gran Voluntad. De todos modos la filosofía llegaba a una constatación aparentemente lisonjera: el hombre es "hijo" de Dios ${ }^{3}$.

También la religión de Israel daba por supuesto el mito y partía de él, pero

1 G. GuSDoRF, Mito y.Metafísica, 1960. Platón inventó el término "teología" para suplantar el de "mitología", pretendiendo someter el mito y la profecía a la dialéctica. W. JAEGER, La Teología de los primeros filósofos griegos, México 1947,10 y 194.

2 La teología de los griegos es "natural". La aproximación ail "theos" por medio del "logos" significa sumisión del "theos" a la lógica humana. E. CAIRD, The Evolution of Theolagy in the Greek Philosophers, 2 vols., Glasgow 1904; P. E. MoRe, The Religion of Plato, Princeton 1921. La dialéctica o lógica humana termina en abstracción, eliminando tiempo, movimiento, evolución, libertad, historia, memoria, acción, etc.

3 E. BRUNNER, Gott und Mensch, Tübingen 1930, 3 ss. El realismo es objetivismo, causa formal, analogía propia: Dios es Ens Realissimum. El idealismo es subjetivismo, logos: Dios es el Logos Supremo y Absaluto. En el monismo panteísta se identifican sujeto y objeto. 
de otra manera. Gracias a la noción de "creación", el hombre carecía de cordón umbilical y no tenía por qué cortarlo. Adán nunca tuvo cordón umbilical. En lugar de una dialéctica, aparece el mensaje, la palabra, la revelación. La Natura queda a un lado, problematizada, y el hombre tiene que detenerse ante un "Theos" trascendente, personal, creador. Aquí se corta el mito: el hombre no nace de Dios, no es hijo de Dios, con causalidad formal; aparece sin padre ni madre. Aparece "fabricado", con una causalidad de creación. Aquí no hay "revelación natural", a no ser cuando el hombre tiene ya la clave revelada para entender la Naturaleza. El profeta de Israel, en oposición al filósofo, no depende de ley, dialéctica o filosofía alguna: depende de la libertad. Pero la libertad es Dios mismo, ya que el profeta habla y existe en nombre de Dios: es un mero órgano o instrumento, causa instrumental. El profeta no nace, pero tampoco se hace. Aquí no reinan las leyes, sino los hechos, la historia, la libertad, el tiempo, el movimiento, todo aquello que pretende dominar y superar la filosofía ${ }^{4}$. La religión se presenta como un modo radicalmente distinto de ser, frente a la metafísica o filosofía. Frente al término "teología" tendríamos que marcar el término "panteísmo", si este término no hubiera sido violentado por la filosofía para algo muy diferente. Aquí no se somete el "theos" al "logos", sino el "logos" al "theos". Dios es un Dios escondido, que se revela si quiere, cuando quiere y como quiere. Pretender deducirlo o inducirlo, ponerlo en evidencia con una ley, sacarlo a plaza con una dialéctica, es una ilusión infantil ${ }^{5}$.

\section{NOCIÓN Y ESENCIA DE LA IMAGEN.}

La noción de imagen entra en la categoría de relación: necesita dos extremos y un fundamento. En nuestro caso, los extremos son Dios y el hombre. El fundamento es un elemento común que se busca. ¿Pero es que puede haber algo de común entre el hombre y Dios? Sí, así lo ha creído siempre la humanidad. La convicción de que el hombre es un ser diferente de todos los otros, porque lleva dentro una "centella divina", se pierde en la noche de los tiempos. Todas las objeciones que los filósofos han podido soñar para abolir esa univer-

4 En Israel, el hombre se une a Dios mediante la "palabra", no de otro modo: Fichte, al tratar de debatirse contra la realidad, llega a la conclusión de que el concepto de creación est un "contrasentido judaico", porque no se sujeta a ninguna ley. Así, no hay nada que nos revele a Dios, sino que el mismo Dios se revela a sí mismo. Otra cosa es saber si puede aplicarse la dialéctica a la revelación divina. Los últimos Libros del Antiguo Testamento dieron testimonio de que el helenismo no había sido una pasión inútil.

5 Cfr. C. Tresmontant, Etudes de Metáphysique Biblique, París 1954, 229. Ermplea el término "metafísica" en sentido acomodaticio e impropio, para opo- " ner un "sistema búblico" a un "sistema gnóstico". En realidad, la Biblia no es una metafísica. 
sal creencia han sido vanas: entre los dioses y los hombres, o entre Dios y los hombres, hay algo de común, una conveniencia, semejanza, analogía, cualidad, divisa, etc. Ya se le considere al hombre como un "hijo", ya se le considere como una "criatura", tiene algo de común con Dios ${ }^{6}$.

No es lo mismo semejanza que imagen. La semejanza abarca mucho más Por eso hablamos de semejanzas de Dios en el mundo físico, pero sólo en el mundo espiritual hablamos de imágenes de Dios. No discutiremos aquí las semejanzas, sino tan sólo la imagen. $Y$ en la imagen hay que confesar siempre una diferencia y distinción previas. Dios y el hombre son diferentes, distintos. ¿Por qué entonces nos preguntamos si el hombre es "imagen de Dios"? Ante todo, pretendemos buscar una "forma": un hijo es la imagen de su padre, porque éste da a aquél la especie. También tratamos de señalar una cualidad o forma accidental: así, la estatua o el mono son imágenes del hombre por la figura. En fin, nos fijamos en una cualidad: este hijo es imagen de su padre, en oposición a los otros hijos, porque le imita mejor.

Y puesto que el hombre no tiene naturaleza divina, sólo podrá ser imagen de Dios por alguna cualidad o semejanza accidental. Pero el hombre no se contenta con cualquier analogía o semejanza, sino que quiere llamarse "imagen", atribuyéndose de algún modo una comunidad de forma ${ }^{\text {? }}$.

\section{LA IMAgen DE Dros EN EL HELENISMO.}

Los sofistas fueron los primeros que dieron a la imagen de Dios un significado y un valor filosófico: presentaban la figura vertical y la mirada del hombre hacia adelante, como carácter específico del mismo, como imagen de Dios, como prueba de la superioridad sobre el resto de los animales ${ }^{8}$. De estos sofistas arranca una tradición que hallamos ya en Jenofonte: el organismo humano es una prueba de la existencia y de la providencia de Dios: "los dioses hicieron erecto sólo al hombre entre todos los animales; porque camina erecto y, con la mirada dirigida hacia adelante, ve y evita los peligros, y se cuida de sí mismo" 9 . Conforme al mito del Protágorás, la naturaleza es para el hombre una madre, no

6 Cfr. H.-G. PoHLmann, Analogia entis oder Analogia fidei?, Göttingen 1965. Responde bien a los prejuicios de K. Barth.

7 S. Agustín, Solitoquios, II, 6, 10-32, PL. 32, 889-900 s. La imagen puede llegar a la igualdad perfecta; en cambio, la semejanza exige siempre un hecho diferencial. Tanto en Grecia como en Israel se busca en la imagen una "potencia de conocimiento". Cfr. A. SCHNEIDER, Der Giedanke der Erkenntnis des Gleichen durch Gleichen in ant. u. patr. Zeit, Münster 1923.

8 Cfr. S.-O. DrCKERMAN, De argumentis quibusdam apud Xenophontem, Platonem, Aristotelem, e structura hominis et animalium petitis, Halle 1909, 93.

9 JENOFONTE, Memor: 14. 
una madrastra, puesto que, aunque el hombre viene al mundo desnudo y desamparado, puede vivir como los dioses ${ }^{10}$. En adelante, la imagen de Dios conservará siempre ese carácter polémico inicial.

Platón se adentra en el modo de presentar la imagen. Ya no se fija en el exterior sino en el interior del hombre: el hombre exterior es sólo signo del hombre interior ${ }^{11}$. La diferencia específica del hombre es la vida filosófica, el poder contemplar las normas de un mundo trascendental y aplicarlas a la vida: tal es la frónesis ${ }^{12}$. La imagen de Dios es la frónesis. De este modo Platón, al oponerse al empirismo individualista, relativista y subjetivista de los sofistas, arrastra la imagen de Dios hacia la zona de la eternidad de los valores y normas categóricos. Porque el alma del hombre camina erecta, y mira hacia el mundo inteligible, ella se queda con la imagen de Dios, mientras que el cuerpo es asemejado más bien a los animales. La filosofía protréptica y la Diatriba, lo mismo que los estoicos, cínicos y moralistas, adoptan esa postura como un tópico: hay un bomo incurvatus in terram y también un bomo erectus in coelum.

Una vez establecido el dualismo platónico, de indudable origen religioso, órfico y pitagórico, según la teología de los misterios, Platón concluye que la parte superior del alma es "divina" y reside en la cabeza del hombre ${ }^{13}$. Es una referencia al Cielo, del que el alma bajó y al que tiene que ascender: el Cielo, lo divino, el Mundo Inteligible, es la Patria, génesis, y telos del alma, lugar de partida y término de arribo. Se establece así una articulación natural: preexistencia, caída, olvido, despertar, vigilancia, regreso, catarsis, iluminación, unión definitiva ${ }^{14}$. Cada hombre posee un dáimon interior y tiene que salvarlo: lo salva cuando lo escucha y obedece, cuando entra en la vida filosófica, viviendo con "rectitud": esa es la omóiosis Theou, la imagen de Dios realizada ${ }^{15}$. Así convirtió Platón la religión en filosofía, suprimiendo el culto y la moral, presentando la vida filosófica como redención y salvación.

Pero, por otra parte, Platón aceptó lo corporal como símbolo de lo espiritual. Si la "erección" corporal era símbolo de la espiritual, el Cosmos es un "Dios sensible", imagen del Dios Inteligible. De ese modo arrancan también de Platón otras teorías de la imagen de Dios, tales como las que hallamos en Aristóteles y los estoicos, en esa religión astral, en la que se rechaza la trascendencia

10 Platón, Protágoras, 320 C ss.

11 Platón, Timeo, 90 A-D.

12 Platón, Politeia, IX, 585 B s.; Fedro, 246 A ss.

13 Platón, Timeo, 90.

14 Cfr. E. Rohde. Psyche, II, 1898; H. Neugevauer, Platonische Mystik. 1934 ; J. van CAMP y P. CANART, "Le sens du mot "theios" chez Platón": Recueil de travaux d'hist. et de philologie, 4 serie, 9 (1956) 174 s., 409 s. Véase la diferencia entre soma y sema. en Platón, Gorg. 493 a; Cratilo, 400 C. Los términos períbolos y desmoterion, cárcel, proceden de los órficos.

15 PLatón, Timeo, $47 \mathrm{BC}$; Theaitetos, 176 B. 
platónica, en la que Dios vuelve a ser inmanente, y el estado erecto del cuerpo humano vuelva a ser un argumento de la existencia y providencia de Dios ${ }^{16}$.

Los latinos, especialmente Séneca y Cicerón, recogen la herencia griega y la popularizan dentro del estoicismo materialista, de la religión astral, y de la filosofía edificante, con la que se pretende llevar algún consuelo a los espíritus escépticos. Dios sacó a los hombres de la tierra, pero los construyó erectos, mirando al cielo, aludiendo al conocimiento de los dioses. Los hombres son semejantes, o más bien iguales a los dioses, excepto en la inmortalidad ${ }^{17}$. Aun podría decirse que son superiores a los dioses, ya que éstos no pueden ejercitar muchas virtudes que implican mortalidad, como por ejemplo, la paciencia en la adversidad, el valor ante el riesgo, la serenidad en el dolor ${ }^{18}$. El panteísmo estoico, que divinizaba el cosmos, divinizaba también al hombre: todo termina en la apoteosis.

La orientación práctica, dada a la filosofía estoica, invitaba a fijarse sobre todo en el ejercicio de la virtud. La imagen de Dios es la virtud moral. La contemplación del cielo se ordena a la imitación de la regularidad y orden de los astros: el orden celeste es el modelo que el sabio tiene que imitar en su vida. En lugar de insistir en que el hombre "es" imagen de Dios, se insiste en que "tiene que" asemejarse, imitar a Dios, seguir a Dios. Sequere Deum es la fórmula estereotipada para designar la virtud. Pero ese Dios es la misma naturaleza, la regularidad, orden y constancia de las leyes naturales o físicas, lógicas y morales. La rectitud y la semejanza platónicas perduran en esta fórmula sequere Deum ${ }^{19}$.

16 Cfr. P.-H. Merki, Omóiosis Theô, Freiburg i. Sch. 1952; K. GaISER, Protreptik und Paränese bei Plato, Tübingen 1959; P. Frutiger, Les Mytes de Platon, París 1930; H.-W. THomas, Epékeina. Untersuchungen über das Uberlieferungsgut in den Jenseittsmythen Ploutos, München 1938; PLATón, Timeo, $92 \mathrm{C}, 29 \mathrm{~B}, 30 \mathrm{~B}, 31 \mathrm{C}, 34 \mathrm{~B}$. La filosofía griega se ve totalmente dominada y condicionada por dos factores: el dualismo cosmológico y la inmanencia naturalista. La misma trascendencia platónica, que parece rigurosa, supone que las almas "preexisten", que vienen de arriba, como el entendimiento agente de Aristóteles.

17 SÉNECA, Epp. 31, 9; 59, 14;87, 19;92, 30.

18. SÉNECA, Epp. 53, 11 s.; 73,$14 ;$ De Prov. $6,6$.

19 Astromum ortus obitus cursusque... quae contuens animus accedit ad cognitionem deorum, e qua oritur pietals, cui conjunctia justitia est reliquaeque virtutes, e quibus bleata vita existit, par est similis deorum, nulla wilia re nisi immortalitate, quae nihil ad bene vivendum piertinet, aedet caelestibus. CICERóN, De Natura Deorum, II, 61, 153; SÉNECA, Epp. 95, 47; 90, 34; 95. 50; De Ira, 2, 16, 2; Ben. 4, 25, 1. Estos filósofos latinosi utilizan la "imagen" de los" sofistas, de los platónicos y de losi estoicos, según les convenga. Pero toda su filosofía está dominada por un escepticismo angustioso, como se ve en el De Natura Deorum, de Cicerón. Después de tanto discutir, no se ve claro que existan los tales dioses. Se trata sólo de una creencia piadosa. 


\section{LA IMAgEN DE DIOS EN ISRAEL.}

El pueblo de Israel se halla rodeado de una vieja cultura en la que la causalidad formal y naturalista había triunfado antes que en Crecia. Para estos orientales es ya un dogma que Dios comunica su vida, y que toda la fecundidad del universo ha de ser referida últimamente a Dios. En un ambiente semejante, afirmar que el hombre en general o que algunos hombres concretos son hijos de Dios sería corriente, pues de esta cultura ha pasado tal persuasión a la griega. El Faraón de Egipto era considerado de hecho hijo de Dios. Hacia el año 2000 antes de nuestra era afirmaba ya el sabio Merikaré que el hombre era "imagen de Dios". Los misterios de Egipto y Babilonia demuestran que ambas culturas admiten en el hombre un elemento "divino", aunque no acierten a precisar científicamente cuál es ese elemento.

Cuando el Jahvista publica su síntesis, el hombre aparece compuesto de dos elementos: la tierra y el espíritu. Este espíritu le viene de Dios, puesto que Dios sopló al rostro de Adán y le constituyó en ser viviente. Dios crea para él la mujer, pero en toda la creación no existe ser alguno que pueda compararse con el hombre y la mujer: sólo ésta es hueso de los huesos y carne de la carne de Adán. Todos los demás seres son de otra especie. Ahora bien, ese hombre aparece como "imagen de Dios", aunque no se haga expresamente la afirmación: conversa normalmente con Dios y vive en un universo que hoy llamaríamos "sobrenatural". Dios es un espíritu y el hombre es también un espíritu: no se trata ya de fuerzas naturales o de fuerzas políticas. Dios y el hombre no pertenecen ni a la Natura ni a la Polis. Por otra parte, Dios planta un paraíso para Adán, escoge a Adán para que lo trabaje y custodie, se cuida de él, incluso después de haber sucumbido Adán a la tentación. Es claro que el Jahvista proyecta sobre Adán la teología de Israel y piensa en el paraíso que pudiera haber sido la Tierra Santa, de no haber sido por la tentación y la caída. De todos modos, Adán es presentado como "siervo" de Dios, como representante, cachicán o vicario de Dios a la manera que Israel es "siervo de Dios" o "hijo de Dios".

Esa teología del Jabvista se desarrolla más aún en el Elobista. El Deuteronomio predica con frecuencia que el hombre y que el pueblo son "hijos" de Dios, en sentido adoptivo y de gracia. Pero el texto más famoso de la Biblia es Gen. 2, 7: afirma que el hombre fue creado a imagen y semejanza de Dios, y pertenece al Código Sacerdotal ${ }^{20}$. La caída de Jerusalén provoca una catástrofe religiosa, al desvanecer las esperanzas supersticiosas del pueblo. ¿Ha sido vencido Jahvé por los dioses de Babilonia? ¿Se ha cansado Jahvé de su pueblo? ¿Rechaza el

20 J, JeRvel, Imago Dei, Göttingen 1960, 21 ss. 
Pacto? ¿ $\mathrm{O}$ es que quizá no existe Jahvé? Como siempre, la reacción depresiva despertó en los dirigentes de Israel la voluntad de defender su fe con motivos más elevados y plásticos. Por eso, el Código Sacerdotal insiste: la omnipotencia de Jahvé es indiscutible: es el Creador del mundo. En cuanto a su fidelidad al Pacto con Israel, es igualmente indiscutible: El hizo a Adán a su imagen y semejanza. El sentido obvio y elemental de este famoso texto es éste: Jahvé considera al hombre como representante suyo, como hijo, réplica, enviado o comisionado. Jahvé se considera a Sí mismo, como modelo o dechado u original, al mismo tiempo que como Creador del hombre.

Tenemos, pues, ante nosotros una teología que se apoya en una "analogía" intrínseca y esencial: el hombre es una imagen "formal" de Jahvé, una imagen "natural" básica. Dentro del concepto de "pacto", que es la clave para entender la religión de Israel, la imagen analógica significa que Jahvé instituye oficialmente a Adán como "hombre". Ser "hombre" significa poseer un "pacto" fundamental y principal, un estatuto ontológico, un hábito estable, un carácter indeleble. Ser "hombre es una suerte de oficio o profesión ${ }^{21}$.

La imagen de Dios no se perdió con el pecado, ya que entonces automáticamente habría desaparecido el estatuto religioso del hombre, la responsabilidad del fuero o pacto. Así Adán trasmite a su hijo Seth la imagen que recibió de Dios ${ }^{22}$ y se promulga la ley de que el respeto a la vida humana se funda en que el hombre es imagen de Dios ${ }^{28}$. Tal ideología se mantiene en Israel con tal constancia, que todavía en el Nuevo Testamento se dice que el hombre lleva la imagen de Dios como una moneda lleva la del César ${ }^{24}$, que el varón no debe cubrir su cabeza por ser imagen de Dios ${ }^{25}$ y que el hombre es imagen de Dios por el mero hecho de ser un hombre ${ }^{26}$. Toda esta tradición ideológica descansa en el texto del Código Sacerdotal, en que se habla de la creación del hombre a imagen de Dios.

Dos tipos de exégesis de ese texto hallamos en el judaismo. El primero, antropológico, ético, sapiencial, va encabezado por el Siracida ${ }^{27}$. El fundamento de

\footnotetext{
22. Gen. $5,1$.

Gen. 5, 3.

Mt. 22, 20.

I Cor. 11, 7.

26 Jac. 3, 9; G. von RAD, "Eikón": Theol. Wörterbuch, Kittel, II, 390; ID., Das erste Buch Mose, en A. T. D., al texto Gen. 1, 26; H. bei STAmM, Die Imagolehre von $K$. Barth $u$. d. altest. Wiss., para el 70 Onomástico, Zollikon 1956, 89 ss.; K. L. ScHMIDT, "Homo, imagro Dei": Eranos Jahrbuch 15 (1947); ID., Der Mensch, Zürich 1948; E. BRuNNER, Dogmatik, Zürich 1950, II. 67; P. Brunner, "Der Ersterschafene als Gottes Ebenbild": Pro Ecclesia, Berlín $1952,1.962$.

27 Ecoli. 17, 1-4. El siracida combina en ese texto Gen. 2, 7 con Gen. 1, 27 para idescribir la creación del hombre y el sentido de esa creación.
}

21 H.-G. Pohlmann, Analogia entis oder Analogia fidei?, Göttingen 1965, 
la relación entre Dios y el hombre es la potencia, el poder: Dios crea al hombre para dominar la tierra, y así le dota con poderes oportunos, como quien nombra un embajador y le entrega las credenciales: el hombre es un embajador, un pequeño Jahvé para la tierra. Mas, como no se mira tanto al dominio real sobre la tierra, cuanto al dominio de sí mismo, que es el medio para dominar la tierra, hemos hablado del carácter "ético" de la imagen; éste reside en la vida moral, en el temor y amor de Jahvé.

El segundo tipo de interpretación, de carácter más histórico y especulativo, lo hallamos en el Libro de Henoch ${ }^{28}$. Dios creó al hombre y le dotó de un órgano de percepción para distinguir el bien del mal. Se pasa por alto que el conocimiento del bien y del mal se presenta en Gen. 3, 22, como una consecuencia del pecado original. La imagen consistiría en el conocimiento moral y en la libertad de hacer el bien o el mal. Hallamos esa misma interpretación en la Sabiduría de Salomón ${ }^{29}$ : la imagen de Dios es la inmortalidad, la eternidad, aidiótes, para la que fue creado el hombre: esa eternidad o inmortalidad depende de su justicia, y por eso Dios creó al hombre a su imagen al dotarle de la potestad de ser justo e inmortal. Aparece aquí el dualismo antropológico, en cuanto que sola el alma es imagen de Dios y es destinada a la inmortalidad, mientras el cuerpo vuelve al polvo: polvo eres y en polvo te convertirás ${ }^{30}$.

Como se ve, la imagen le Dios está orientada en el sentido de la "justicia" o santidad. Dios creó todas las cosas en el orden ${ }^{31}$ y el hombre es responsable: no tiene escapatoria posible dentro del pacto con Dios: Dios conoce todos los detalles de la vida moral y de la fidelidad, puesto que creó al hombre y conoce su facultad de hacer el bien y su libertad. La creación y el orden van siempre juntos en el judaismo postexílico: el orden humano ha de ser una imagen del orden divino, y así el hombre es siempre imagen de Dios, pero la imagen se desarrolla y progresa indefinidamente en un orden de "semejanza". La imagen de Dios exige una responsabilidad y un juicio de Dios, pero da al hombre el dominio sobre los animales y sobre la tierra.

Para entender mejor el sentido de la exégesis postexílica, recordemos que el Génesis dice: "hagamos al hombre a nuestra imagen" 32 . ¿Por qué ese plural "hagamos"? Algunos de los exégetas se limitaron a omitir este versillo, ahorrán-

28 Henoch, 65, 2: “Creó al hombre a su propia imagen, le dio ojos para ver, oídos para oír, cơrazón para pensar, razón para dominar...”.

29 Sap. 2, 23: "Porque Dios creó al hombre para la inimortalidad, y le hizo a imagen de su propjo ser. Mas por envidia del diablo entró la muerte en el mundo...". Si Dios creó todo en el orden, taxis, el pecado se sale del orden, es un desordien, ataxía.

30 Gen. 3, 19; Eccle. 12, 7; Job. 7, 21; 20, 11; 21, 26.

31 Esa es la sustancia de un gran número de textos, entre los que destaca San. 11, 20: Dios lo creó todo con número, peso y medida. Con esia tríada se indica el orden, taxis, que en realidiad se refiere a la Torah o Ley de Moisés.

32 Gen. 1, 26. 
dose así las complicaciones innecesarias. Por el contrario, la literatura sapiencial puso de relieve precisamente ese versillo. Pero provocó polémicas, como si ese "hagamos" pusiera en peligro el monoteísmo de Israel. El Libro de los Proverbios, preocupado por el gravísimo problema de la trascendencia divina, busca un "intermediario": identifica la "Sapiencia" con el "Principium" (Bereschit) del que se habla en el principio del Génesis ${ }^{33}$. El Libro de la Sabiduría nos presenta a la Sapientia como órgano, instrumento o Intermediario de la creación ${ }^{34}$ : es Eikón, imagen de Jahvé; en cuanto tal, posee el dominio, la moralidad, el orden, y entrega esas propiedades al hombre, porque también éste es imagen de Dios; y lo es por esos caracteres y propiedades. El Eclesiástico ${ }^{35}$ da una extensa exégesis, tratando de definir como imagen de Dios las facultades más específicamente humanas y presentando de este modo al hombre como bomo religiosus: la facultal máxima del hombre es poder captar y entender la "palabra de Dios", pues de ese modo queda definida la relación fundamental del hombre con Dios. En tales textos se ve claramente que la imagen no se perdió con el pecado original, que esa imagen es independiente del pecado y de la gracia de un redentor. El hombre pecador continúa siendo hombre ante Dios, con toda su responsabilidad, por esa analogía formal. El pecado del hombre puede quebrantar el "pacto", pero no suprimirlo, ya que el hombre existe como tal en virtud de ese pacto.

¿Por qué, entonces, la polémica? Porque la Sapiencia Mediadora no parece ya un atributo abstracto o poético de Jahvé, sino una Persona, o a lo menos una Personificación, que implica peligro de politeísmo. Por eso el $I V$ de Esdras se opone a este modo de ver y afirma resueltamente: nadie ayudó a Dios en la obra de la creación ${ }^{36}$. El Libro de Enoch insiste en que Dios creó todas las cosas por Sí mismo, y sólo para crear al hombre se valió de la Sapiencia ${ }^{37}$. Se ve, pues, que, mientras para unos la verdadera imagen de Jahvé es la Sapiencia, y el hombre ocupa un lugar secundario y consecutivo como "imagen de la imagen", para otros la imagen verdadera de Jahvé es el hombre, y se procura no hablar de la Sapiencia personificada por temor al politeísmo.

Todavía podríamos apuntar una tercera exégesis, o más bien un espíritu de exégesis: dentro de ese sentido la imagen tiene carácter nacionalista. Jahvé colocó a Adán en el paraíso, como colocó a Israel en la "Tierra Santa", esto es, como

33 Prov. 8, 22: "Jahvé me creó en el principio de suss planes...".

34 Sap. 7, 25 s.: "Es' (la Sapiencia) un hálito del poider de Dios, emanación pura de la gloria de Dios... Es el resplandor de la luz eterna, espejo sin mancha del actuar de Dios, imagen de su bondad:...".

35 Eccli. 17, 2-12: "Creó el Señor al hombre de la tierra... y le dio poder sobre los seres que en ella existen. Lo revistió de fuerza como El mismo y conforme a su imagen lo hizo...".

36 IV Eisdras, 3,$4 ; 6,6,39$.

37 II Henoch, 30, 8: "Cuando terminé todo, mandé a mi Sapiencia que creara al hombre..." 
representante suyo, como su imagen. Solos los israelitas son imagen de Jahvé, representantes suyos; por ende, Adán es considerado como padre de Israel, no como Patriarca general de los hombres ${ }^{38}$.

Tenemos, pues, tres interpretaciones: a) La imagen es ciencia y libertad morales; el pecado original tiene aquí escasa influencia; b) La Imagen es la Sapiencia, que colabora con Jahvé; el hombre es copia de la Imagen; c) La imagen de Adán es para Israel: Israel tiene que dominar a todos los pueblos, pues es imagen de Jahvé.

Según se va acentuando más y más la trascendecia de Dios, se va Dios envolviendo en la nube impenetrable. El hombre ya no puede ver a Dios y continuar viviendo; por lo mismo, la imagen se va distanciando del original. El verbo "conocer", que implicaba trato familiar, va siendo excluído del terreno religioso o interpretado como "servir y adorar a Jahvé". Cada vez aparecen nuevos intermediarios entre las criaturas y el Creador. Las causas segundas van adquiriendo independencia relativa. La Creación aparece como un Ordo, garantizado por el Creador ${ }^{39}$. El Universo se convierte de este modo en un espejo de la divinidad: los cielos cantan la gloria de Dios ${ }^{40}$. Lejos de significar un peligro para la trasdencia divina, las "imágenes y semejanzas", esto es, los antropomorfismos y cosmomorfismos, son utilizados para acentuar la trascendencia: nosotros sólo tratamos con "imágenes", no directamente con Dios.

El Exodo agudiza el problema, al afirmar que Moisés vio directamente a Jahvé. En algunos textos se dice que lo vio de espaldas, pero en otros se afirma rudamente que lo vio cara a cara ${ }^{41}$. En el Sinaí se toman precauciones para que nadie se acerque; el viejo terror de lo "santo" se incrementa. Ya no se puede pronunciar el "Nombre", fuera de los actos de culto. Los términos Schékina (Presencia), Dabar (Palabra), Memra (Voz) y Kol (Sonido), van cobrando personificación; son hipostasiados o convertidos en "ángeles". La Sofía y el Pneuma son

38 . Cfr. J. JerveL, Imago Dei, Göttingen 19:60, 119 s.

391 Cfr. G. von RAD, Theol. des A. T., München 1957, I, 149. 1965,44 ss.

40 Cfr. H.-G. Pohmmann, Analogia entis oder Anoilogia fidei?, Göttingen

41.Visión faciall: Ex. 33, 18-23; Deut. 5, 24-27; Ex. 33, 11; Núm. 12, 6 ss. Visión atenuada: Deut. 5, 24-27; Ex. 20,19; Deut. 18, 16.

Visión simbólica: Is. $6,1,8 ; E x .1,16 ; 2,1 ; 2,9 ;$ Dan. 7, 9.

Cfr. Fr. MichaELI, Dieu á l'image de l'homme, Neuchatel-París 1950, 77-100; H. RINGGREN, Israelitische Religion, Stuttgart 1963, 276 sS.; A. OEPKE, "Nephele": Theol. Wörterbuch, Kittel, IV, 907. La tradición judía terminó distinguiendo tres grados en la visión de Dios: a) ver la fiorma de Dios (Moisés); b) ver a Dios desde lejos (Aarón, Nadab, Abiu y los Setenta Ancianos); c) ver manifestaciones externas o simbólicas de Dios en las teofaníass (el Pueblo). Cfr. H. van OYEN, Theologische Erkenntnislehre. Zürich 1955, 117-126. Todas las tensiones interiores del ser humano proceden de que el hombre ess "imagen" de Dios. También en este orden podríamos adimitix": estamos en el mundo, pero no somos del mundo. 
tratados de modo que parece anunciarse ya el Nuevo Testamento. Y siempre está en litigio el problema de la "imagen".

\section{La imagen en Filón de Alejandría.}

Filón reúne el judaismo y el helenismo, la filosofía y la revelación de un modo interesante. No traiciona a su sangre judía ni a su cultura bíblica y religiosa; pero estima que la Filosofía fue una gracia que Dios otorgó a los griegos, como otorgó la Ley a los judíos. Su norma es pues "Ley y Filosofía".

Muchas veces se refiere a la imagen de Dios, al exponer Gen. 1, 26. Pero su exégesis se apoya siempre en dos puntos de vista:

1. La imagen de Dios es el Logos. El hombre fue creado a imagen del Logos. Finalmente, por referencia a Gen. 2, 7 (inspiravit in faciem ejus spiraculum vitae), la imagen de Dios en el hombre tiene también carácter pneumático.

2. Cuando se refiere a este último texto, hay que aplicarlo al hombre terreno, colocado por Dios en el Paraíso. En cambio, cuando se refiere al primer texto (Gen. 1,27), hay que aplicarlo al hombre ideal y platónico, a la idea celeste del hombre terrestre.

La imagen propiamente dicha es el Logos, que salva la trascendencia platónica y es Intermediario entre el Creador y la Creación ${ }^{42}$. Es un Logos personificado, divino, preexistente: es representante de Dios, para regir y gobernar el mundo, para ser providencia y guía de los hombres, para revelar a los hombres el conocimiento de Dios y la esencia de Dios por el camino místico. Dios, el Dios escondido, incognoscible e indefinible, es el Ejemplar originario, el Parádeigma. El Logos es su Imagen o Copia, Eikón, Apekónisma. Pero, si relacionamos al Logos con el hombre, entonces el Logos se convierte en modelo o ejemplar, Archétypon, Parádeigma. $\mathrm{Y}$ en este caso el hombre finalmente es "imagen de la imagen" ${ }^{43}$. El alma humana está compuesta de sangre y espíritu divino (pnéuma thêion) o nous, inspirado por Dios en el rostro de Adán: es pues sustancia divina, moira, apóspasma ${ }^{44}$. Por otra parte, reserva la imagen de Dios a los místicos o

42 FILón, Leg. Alleg. III, 96; De Somn. I, 226-230. Según Filón, por lo tanto, cuando Dio's dice en el Génesis "hagamoslal hombre" (Gen. 1, 26), este homibre es la idea de hombre en el Logos, pues Jahvé habla con el Logos. En cambio, en el versillo siguiente, cuando dice "Dios creó al hombre a su imagen", ese hombre es "la idea de hombre en ella misma". El primero es un hombre logo-lógico; el segundo es un hombre ideo-lógico. Finalmente el versillo 2, 7 : “Formó al hombre del polvo y le insuffó...", se refiere al hombre actual, concreto y empírico. J. Jervelu, Imago Dei, Göttingen 1960, 54; H.-A. WolfsoN, Philo, 2 vols., Cambridge 1948, I, 239.

43. Dios' no hizo al hombre imagen, sino a imagen. FILón, Lég. Alleg. III, 96; Quis rer. div. 230-232.

44 ID., De Op. Mundi, 123. Cfr. J. JeRVELL, Imago Dei, Göttingen 1960, 57 s.; Fruón, Leg. Alleg. III, 100-102; Dee Somn. II, 228; QG. III, 55, y IV, 25. 
pneumáticos, pues solos ellos llegan a ver "lo semejante por lo semejante". Todo esto es confuso: parece querer decir que todos fueron hechos a imagen de Dios pero solos los peneumáticos llegan a ser "imagen", semejante a Dios. Las confusiones parecen provenir de una contaminación gnóstica de alguna especulación sobre el Antropos, propia del gnosticismo. En suma, Filón está dominado por la teoría platónica del Logos. A imagen del Logos fue creada la parte inteligible del alma, el Nous o Pneuma. Mientras Gen. 1, 26 es interpretado en sentido pneumático, logológico, Gen. 1, 27 es interpretado en sentido ideológico, platónico (hombre ideal). Sólo en Gen. 2, 7 empieza Filón a referirse al hombre terreno y empírico, ya en la imagen natural, ya en la pneumática. Algunos puntos accidentales no pueden concordarse fácilmente con estos. Distinguiendo la imagen mediata y natural de la inmediata y pneumática, por la primera subimos del mundo a Dios per ea quae facta sunt, y por la segunda intuimos a Dios directamente. El primer conocimiento se llama Bezaleel; el segundo es Moisés en la Montaña, el conocimiento místico, la imagen propia y auténtica de Dios. El predicado propio de Dios es la inmutabilidad eterna: Deus solus constanter stat. Entendemos así por qué la imagen de Dios se llama "propia", porque el místico o pneumático tiene esa imagen de la eternidad en su alma: ad similitudinem ejus (Dei) constanter stans. Esa aplicación de la "semejanza" parece una aplicación de la teoría estoica o helenista del "sabio". La influencia de Filón en los cristianos es grande.

\section{La imagen en el Nuevo Testamento.}

El Nuevo Testamento se hace eco de la doctrina de la imagen. Especialmente San Pablo. El hecho de que el Apóstol no cite nunca Gen. 1, 27, no debe sorprendernos, ya que sus escritos son epístolas ocasionales. Pero ese texto está siempre ante su consideración. Recoge en un sentido determinado, diferente de Filón, la tradición de su pueblo, refiriéndose también al Logos e identificándolo con Cristo. El problema de la trascendencia divina se resuelve estableciendo la necesidad de una "mediación": Cristo, Virtud y Sapiencia de Dios, es el Mediador universal entre Dios y el mundo, entre Dios y el hombre. La consecuencia inmediata es que el hombre tiene que vivir en la fe y no en la visión, en la iglesia y no en un trato individual con Dios. Esta postura aparece también en otros escritos del Nuevo Testamento, al parecer frente a las pretensiones místicas de algunos "espirituales" o "gnósticos" 45. Pablo estima asimismo que aquí sólo podemos ver a Dios en espejo y enigma, en contraposición a la visión facial ${ }^{46}$.

45 Deum nemo vidit unquam (Jo. 1, 18; I Jo. 4, 12). Quem nullus hominum vidit, sed nec videre potest (I Tim. 6, 16). In quem non videntes creditits (I Ps. 1, 8). Tan solo en el Cielo veremosi a Dios (Mt. 5, 8; I Jo. 3, 3; Mt. 18, 10).

46 I Cor. $13,12$. 
Según la teología paulina, Cristo fue ya "Intermediario" para la creación, tanto en cuanto "Virtud" (principio ejecutivo) como en cuanto "Sapiencia de Dios" (principio ejemplar, modelo) ${ }^{47}$. Corresponde, pues, a Cristo ser por excelencia la Imagen de Dios ${ }^{48}$ y esto ha de aplicarse a la creación del hombre, que fue predestinado para ser conforme con la imagen del Hijo ${ }^{49}$.

Ahora bien, el pecado original cambió el "régimen". Para el israelita estar en gracia de Díos o en desgracia de Dios es lo decisivo, pues de eso depende toda su teología de la historia y toda la historia de la salvación. Una vez que Adán ha pecado y ha caído en desgracia, el "día de Jahvé" no puede ser para él otra cosa que un castigo, un penal. El hombre se convierte en objeto de cólera, en una provocación permanente. El pecado original condiciona el régimen de la vida humana ${ }^{50}$. De este modo, San Pablo contrapone a Adán, como ánthropos, a Cristo, también como ántbropos, y a la humanidad entera como pántes ántbropoi, o polloi ántbropoi, para establecer unas relaciones de pecado ${ }^{51}$. Parece que el judaísmo, en los tiempos anteriores al período cristiano, cultivó ciertas especulaciones sobre Adán, que a veces corren dentro de la ortodoxia, y a veces se dejan influenciar con exceso por las tendencias pesimistas, dualistas o gnósticas del ambiente helenista ${ }^{52}$. A estas especulaciones parece referirse San Pablo, al hablar del hombre terreno y del hombre celeste, cuyas imágenes llevamos o podemos llevar: sicut portavimus imaginem terreni, portemus et imaginem coelestis ${ }^{53}$. Por el pecado de Adán, entra según San Pablo el pecado en el mundo a la manera de una potencia maléfica que toma posesión del universo o de la humanidad ${ }^{54}$. De ese modo, la universalidad y necesidad de la redención de Cristo implica en San Pablo dos cosas: por un lado la universalidad del pecado original, bajo cuya influencia ha caído toda la humanidad sin excepción alguna; por otro lado, la incapacidad de la Ley para sujetar las potencias maléficas y redimir a los hombres. Prescindiendo, pues, de toda presunta teoría gnóstica, dualística o mistérica, es claro que San Pablo sobrepasa con mucho la Apocalíptica y toda la literatura rabínica, y que pone en juego la imagen de Dios. Según San Pablo, la imagen se mantuvo en el hombre a pesar del pecado, pero en un estado deplorable: en ella consiste la llamada "revelación natural" 55. Dios se revela, no sólo en las obras de la naturaleza o de la historia, sino también en los corazones. Con

47 I Cor. 1, 24.

48 Christi, qui est imago Dei (II Cor. 4, 4). Qui (Filius) est imago Dei invisibilis (Colos. 1, 15). Qui, cum in forma Dei esset... (Phil. 2, 6).

49. Rom. 8, 29.

50 Cfr. E. Branderburger, Adam und Christus, Neukirchen 1962, 64 ss.

51 Rom. 5, 12, 21.

52 Cfr. BRANDERBURGer, $O$. c., 135 sis.

53. $I$ Cor. 15, 21-49.

54 Rom. 5, 12-21.

55 Rom. 1, 19 s.; Act. 14, 17; 17, 22; Rom. 1, 21; 2, 15. Cifr. B. GarTner, The Areopagus Speech..., Upsala 1955, 179-198. Cfr. I Cor. 11, 7. 
esa imagen "natural" sólo se llega a un Deus absconditus, como expresa la Epístola a los Romanos: el pagano podía de algún modo conocer a Dios, pero no podía alcanzar la salvación. Se mantenía una "imagen formal", una analogia entis ${ }^{56}$ entre Dios y el hombre, pero en estado tanto más deplorable cuanto que era incapaz de restaurarse a sí misma. Si el pagano conserva la imagen, mejor la conserva el judío, pero también en estado deplorable e impotente.

Así, pues, le corresponde a Cristo darnos la imagen de Dios, que nos salva, restaurando así la imagen natural, que habíamos deteriorado bajo el poder de las tinieblas. Tiene que imprimir en nosotros la imagen pneumática, reproduciendo así la doxa o gloria de Dios en nosotros. Tal es la justicia o santidad de Dios, que se presenta como un comentario a Gen., 1, $27^{57}$. Esta nueva revelación que es Cristo, y que se opone al velo que la Sinagoga lleva sobre el corazón, aparece en la Ecclesia. Cristo y la Iglesia son el "espejo" de Dios. El cristianismo ha de ser "conformado" con Cristo, recobrar la imagen completa. El hombre nuevo o pneumático, en oposición al viejo o psíquico, es "sobrenatural". Y puesto que el rostro es la expresión de la "forma" o "especie", tenemos que llevar en el rostro la imagen de Cristo, para que de este modo Cristo sea nuestro "redentor".

Dios nos predestinó para conformarnos a la imagen de su Hijo, para que El sea Primogénito entre muchos hermanos ${ }^{58}$. De ese modo, llegamos a participar de la "forma de Dios" de un modo real, ya que la redención es real: quedamos así reintegrados a nuestro paraíso, hijos de Dios, con adopción mística y no sólo jurídica, pues llevamos impresa en el rostro la imagen divina. Cristo vive en nosotros, como el Espíritu que se movía sobre las aguas en el caos primitivo. La imagen sobrenatural tiene ya carácter cristológico, soteriológico y escatológico.

El Nuevo Testamento acepta pues dos imágenes diferentes de Dios: la natural y la sobrenatural, formal y material, creacional y redencional, esencial y accidental. El telos cristiano de la vida consiste cabalmente en esto: en ser conforme, synmorphos, con la imagen, eikón, del Hijo de Dios ${ }^{59}$. El cristiano contempla a Cristo, gloria de Dios, y según $\mathrm{El}$ se va transformando ${ }^{60}$ y renovando ${ }^{61}$.

56. H.-G. POHLMANN, O. c., 1.301.

57 Cfr. J. JeRwel, O. c., 174 ss. Sobre la relación entre Eikón y Doxa, propia del judaismo y que se refiere a Moisés, señalando el rostro como lugar en que se manifiesta la imagen ide Dios, véase: $I$ Cor. 11,$7 ; \operatorname{Rom} .1,23 ; 8,29 \mathrm{~s}$. Cfr. "Doxa": Theol. Wörterbuch, II, 236-255.

58 Rom. 8, 29 s.; Col. 1, 15; II Cor. 4, 4; Fil. 2, 6; Col. 3, 10; Eiph. 4, 24. Cristo, imagen de Dios, es pues: a) modelo para la creación del hombre; b) para la recreación de la imagen en el bautismo; c) para la restauración progresiva de la imagen natural o formal, mediante la vidá sacramental y ascética; d) para la madurez perfecta en la resurrección. Cifr. G. WAGNER, Das Religiongeschichtliche Problem von Rom. 6, 1-11, Zürich 1962.

59 Rom. 8, 29.

60 II Cor. $3,18$.

61 Col. 3, 10. 
Por la divinidad de Cristo, el cristiano, que copia a Cristo, se convierte en imagen renovada de Dios.

Ambas imágenes no se oponen, sino que se continúan ${ }^{62}$. La imagen natural es como el continente de la sobrenatural, aunque el contenido da sentido y perfección al continente. La gracia no viene a destruir la naturaleza sino el vicio de la naturaleza, como dirá San Agustín. La imagen natural empieza a ser perfeccionada, libertada, santificada, glorificada. Así se llegará un día a la imagen perfecta del cielo ${ }^{63}$.

En los demás autores del Nuevo Testamento prevalecen dos aspectos de la imagen. El primero responde al contraste que ofrece San Pablo en Rom. 1, 23, y que en el Apocalipsis toma la fórmula "imagen de la bestia", que puede referirse a todo género de idolatría, ya sea a la imagen del César, ya a las estatuas de ídolos ${ }^{64}$. El segundo concepto se refiere a la imagen sobrenatural que se restaura en Cristo, y que en San Juan adopta la fórmula de un "renacimiento" 65. En el primer caso, se pone de relieve el carácter escatológico de la imagen, que da como un derecho de ciudadanía ya para la ciudad de Dios, ya para la Ciudad del mundo. Es una "divisa". En el segundo caso, se pone de relieve el aspecto místico de la imagen, en cuanto que el pneuma divino habita en el cristiano y funda una nueva creación, según vimos en San Pablo. La mística de Dios, propia de San Juan, aparece así un poco diferente de la "mística de Cristo", propia de San Pablo, pues se habla de "inhabitación de la Trinidad". Pero el principio pneumático es el mismo ${ }^{66}$. Ambos aspectos de la imagen tienen en la Patrística gran importancia, pues sirven a los Padres para dar interpretaciones determinadas a la idea fundamental de la imagen de Dios, como veremos.

\section{LA IMAGEN DE DiOS EN LOS GNÓSTICOS.}

Los estudios modernos sobre la imagen de Dios en los Padres abruma realmente ${ }^{67}$. Se está dando la impresión de que se trata de un tema central. Los

62 Cfr. E. BRUNNER, Dogmatik, Zürich 1950, II, 30; P. Althaus, Die christliche Warrheit, Gütersloh 1949, I, 93 s.

63 I Cor. 15, 49; I Jo. 3; 2. Cfr. H.-G. PohlimanN, O. c., 131 ss.; KLeiNHNECHT, "Eikon": Theol. Wörterbuch, Kittel, II, 396.

64 Mutaverunt gloriam-(dóxan) incorruptibilis Dei in similitudinem (omoiómati) imaginis (eikónos) corruptibilis hominis, et volucrum, et quadrupiedum et serpentium (Rom. 1, 23; Apoc. 13, 15; 14, 9 sis.; 15. 2).

65 Nisi quis renaitus fuerit denuo (gennethê ánothen).... (Jo. 3, 3).

66 Cfr. C.-K. BARRET, The Gospel acording to S. John, London 1962, 28-34; R. BultmaNN, Das Evangelium des Johannes, 18 ed., Göttingen 1964, 93-102; C.-H. DODD, The interpretation of the fourth Gospel, Cambridge 1960, 10 ss.; J. HubBy, Mystiques paulinienne et johannique, París 1946. Para la relación entre imagen y conocer, efr. R. BuLrmanN, "Gignosco": Theol. Wörterbuch, Kittel, I, 688-719.

67 Th. Cameinot, "La Théologie de l'image de Dieu”: Rév. sc. pihit. théol. 
Padres Apostólicos no nos han dejado especulaciones sobre este tema, pero se vieron obligados a expresarse en términos y categorías helénicos y a afrontar el riesgo de la interpretación helenística de la Biblia. Sírvanos de ejemplo San Ignacio de Antioquía. Ignacio ve un peligro en que los cristianos discutan con los judíos acerca de Cristo, apoyándose en los textos mesiánicos del Antiguo Testamento. Abandona, pues, el argumento mesiánico y se atiene al místico en el foro interno y al jerárquico en el foro externo. Al cristiano le basta estar "en" la Iglesia, unido "al" obispo. El cristiano mirará en adelante al judío como a un extraño, cuyo lenguaje ya no comprende, y se atenderá al lenguaje de la mística, influído por el helenismo. En el extremo contrario está el docetismo, contra el cual insiste también Ignacio, y el antídoto será el mismo: mística y jerarquía, sacramento eucarístico y obispo. $\mathrm{Y}$ puesto que Cristo es la revelación del Padre, nuestra participación en Dios (metéxis, epitychein) se realiza en Cristo, Ignacio se atiene pues a San Pablo y a San Juan, pero su lenguaje es ya el corriente dentro del helenismo ${ }^{68}$.

Aunque la floración del gnosticismo es posterior a los Padres Apostólicos, cada día vemos con mayor claridad la corriente gnóstica, que como movimiento dualista venía desde tiempos antiguos. Dentro del dualismo fundamental, tan notorio en el maniqueísmo, el gnosticismo acepta siempre de un modo u otro dos dioses. Así Marción distingue un Dios conocido (gnostós) que es el Creador, a quien podemos reconocer en sus obras o criaturas, y un Dios desconocido (agnostós) que es el Redentor, a quien sólo podemos reconocer por Su palabra, por Su revelación. Por la fuerte influencia del helenismo sobre el gnosticismo, la "imagen" juega un papel fundamental en la explicación del mundo divino y humano. Según el testimonio de San Ireneo, los gnósticos fueron los primeros que afirmaron la distinción entre "imagen" y "semejanza" en un sentido técnico.

40 (1956) 443-471; J. GRoss, La divinisation du chrétien d'aprés les Pères grecs, París 1951; A. Slomkowsky, L'état primitif de l'homme dans la Tradition die l'Eglise avant S. Augustin, Strasibourg 1928; A. STRUKER, Die Gottebenbildlichkeit des Menschen in der ersten zwei Jahrhunderte, Münster 1913; E. PETERson, "L'imagine di Dio in S. Ireneo": Scuola catolica 69 (1941) 46-54; S. OTTo, "Der Mensch als Bild Gottes nach Tertulian": Münch. theol. zeitschr. (1959) 276-282; A. MAYER, Das Bild Gattes in Menchen nach Clemens von Alexandrian, Roma 1942; H. Crouzer, Théologie de l'image de Dieu chez Origène, París 1956; R. Bernard, L'image de Dieu d'aprés S. Atanasee, París 1952; W. BurghardT, The Image of God in Man, according to Ciril of Alexandria, Washington 1957; R. LEYs, L'image de Dieu chez S. Gregoire de Nysse, París 1951; W.-R. JENKINsoN, "The Image and the Likeness of God in Man... of Ciril of Jerusalen": Ephem. théol. Lovann. 40 (1964) 48-72.

68 Ignacio, Ad Magnesios 8, PG. 5, 670; 10, PG. 5, 671; Ad Philadelphenses 6. PG. 5, 702; 8, PG. 5, 703; Ad Ephesios 3 y 4, PG. 5, 647, etc. Cfr. H. WERNER-BARTSCH, Gnostisches Gut und Gemeindetradition bei Ignatius von Antiochien, 1940, 11-23. Ya en los tiempos apostólicos se habían experimentado dificultades siempre que los helenistas trataban de interpretar las Epístolas Apostólicas al modo occidental. Piénsese, por ejempilo, en las Epístolas' a los Tesalonicenses. 
Teódoto, de la escuela de Valentín, en los excerpta conservados por Clemente de Alejandría distingue tres hombres: el carnal, el psíquico y el pneumático. El primero posee la imagen de Dios; el segundo posee la semejanza, que es ya algo más; el tercero posee al mismo Dios. Este hombre tercero, místico, lleva en sí una semilla divina, semilla de Dios, plantada en su alma por la Sophia. En virtud de esta semilla divina es primero racional, después espiritual y finalmente celestial. Como se ve, la teoría de la imagen sirve para relacionar a Dios con sus criatura y además para asimilar estas a la naturaleza divina. San Ireneo recoge esas distinciones y las trasmite a los católicos, probablemente influído por esos mismos gnósticos a quienes refuta.

Dos conceptos fundamentales, el primero religioso-soteriológico ${ }^{69}$ y el segundo filosófico-especulativo ${ }^{70}$, animan al gnosticismo. La creación comienza, según los gnósticos, cuando Dios proyecta su imagen umbrátil en las aguas del Caos primitivo. Ya se ve que no hay aquí creación en el sentido bíblico, sino en el sentido helénico de "formación". Pero Dios contempla su propia imagen proyectada, se reconoce a Sí mismo y la Sombra cobra vida y personalidad. Esa nueva Entidad, Ennoia-Eikon es el Antropos, el Espíritu o Pneuma. Así el Padre ha producido a la Sabiduría y al Espíritu. En todo ello no hay unanimidad en los diferentes autores gnósticos, aunque se conserva un fondo general. Según el Poimandres, el Antropos es la segunda divinidad, imagen del Padre. Se confunden fácilmente la Sabiduría y el Espíritu: una u otro son identificados con el Antropos, según los casos.

A su vez la Sapiencia se refleja en las aguas inferiores, contempla su propia imagen, se ama a sí misma y comienza a vivir en el mundo sublunar. Según otra variante, los creadores del hombre, los Poderes, ven la imagen del AntroposSapiencia reflejada en el agua inferior y según ella crean al hombre o antropos terrestre. El gnosticismo nos presenta el amor o "libido" como causa de unión de la Luz con las Tinieblas y nos presenta la "imagen" o Eikón como causa u ocasión de la libido. No se ama la materia sino la imagen, la irradiación. Esto significa que en la materia misma hay un elemento racional, o imagen umbrátil (número): el conocimiento y el eros son dos aspectos de la misma realidad, pues sólo se puede conocer lo semejante por lo semejante (Poimandres), o sea, por una participación de la Divinidad, por una centellă o elemento divino que hay en el interior del hombre. Sólo Dios puede conocer a Dios, sólo lo divino puede

69 Los antiguos tienen de la estatua o imagen un concepto primitivo: la divinidad está presente en la imagen por su esencia o sustancia material. Por eso, las estatuas tenían función religiosa soteriológica por ellas mismas.

70 En el Timeo, de Platón, la imagen tiene función cosmológico-especulativa: mas como las imágenes no participan sustancialmente de las, ideas, estamos ante un misterio. De todos modos, las imágenes son entes que nos permiten pasar a las ideas. Pero el abismo queda abierto, pues la imagen no es nunca inteligible, sino que está en el tiempo y en el espacio. 
conocer a lo divino, y sólo lo pneumático puede conocer o percibir lo pneumático. El elemento divino queda encerrado en la materia, no porque ame la materia, sino porque ama la hermosura, la imagen umbrátil reflejada en la materia ${ }^{71}$. El "yo" es el elemento celeste del hombre, la imagen de Dios, mientras que lo malo es una realidad extraña. En algunos sistemas, la imagen y la semejanza se identifican, mientras en otros la imagen es un grado inferior de la semejanza. Muchas dificultades se ofrecen luego para explicar la imagen de Dios en el hombre por duplicidad de sexo y por la atracción o repulsión sexual, que llega a la obsesión o a la aberración.

\section{LA IMAGEN EN LOS PADRES GRIEGOS.}

Contra este gnosticismo comenzaron a desarrollar una doctrina católica Ireneo, Tertuliano, Hipólito y el Papa Víctor, dando a su especulación un carácter antignóstico y antimonarquiano ${ }^{72}$. Algunos autores retienen su propia inspiración: así, por ejemplo, Taciano acepta la invisibilidad de Dios y su incognoscibilidad, ateniéndose a la doctrina estoica; la diastrophé o disipación nos ha corrompido tanto que ya sólo nos queda la cetellica de la virtud natural ${ }^{73}$; en cambio, San Justino habla de un semen rationis, spérma tổ Theoû, fuerza natural que puso de relieve Sócrates y que se perfecciona con la gracia cristiana ${ }^{74}$. Tan sólo en San Ireneo hallamos expuesta la doctrina de la imagen con alguna extensión.

Suele decirse que Ireneo toma su distinción entre carnales, psíquicos y pneumáticos de la filosofía helenista. Pero probablemente esa distinción la toma de su propia refutación del gnosticismo. Al refutar el concepto de "semejanza" como esa semilla divina de que hablan los gnósticos, identifica la "semejanza" con el Espíritu Santo, don sobrenatural y no don natural, como afirman los gnósticos. Por ende, la imagen no es ya una potencia helénica, sino paulina, sobrenatural. Pero abarca varios aspectos. La imagen aparece ya en el mismo cuerpo humano: Dios formó el cuerpo de Adán, "a semejanza" del Verbo Encarnado, idealmente presente al Creador. Además la inteligencia y la voluntad son rasgos

71 Cfr. J. Jervell, O. c., 141 s.; G. BARdY: DTC. XV, 2, 2.497-2.519; E.-C. BlackmaN, Marcion and his Influence, London 1948, 74 ss.; L. CerfaUX, "La Gnose, essai théologique manqué": Recueil $L$. Cerfaux, I, 264.

72 Los "monarquianos", desde Noeto de Esmirna hasta Sabelio, pasandio por Epígono, Praxeas y Cleómenes, hacían a Dios: "visible en el Hijo, ya que éste era una mera modalidad del Padre. Cfr. Tentuliano, Adv. Praxeam, 6. y 7 , PL. 2, 161.

73 TACIANo, Oratio ad Graecos, 13, 2.

74 S. Justrino, Apologia, 5, 2-4. Afirma que los platónicos le hicienon capaz de "ver a Dios" (Dial. c. Trifón, 2,6); pero luego confiesa que la visión de Dios sólo es posible después de la muerte (Ibid. 4, 5) y que es un puro don de Dios (Ibid. 7, 3). Cfr. A. PUECH, Les Apologistes du II siècle, París 1912, 48 ss. 
que asemejan al hombre con Dios. El hombre entero, cuerpo y alma, fue hecho a imagen de Dios. Pero Adán, además de la imagen, poseyó la "semejanza" o Espíritu Santo, don sobrenatural. Esto último es lo que Adán perdió con su pecado ${ }^{75}$.

La escuela alejandrina, siguiendo la dirección de San Justino, recurre a la filosofía para interpretar o "entender" el Credo. Clemente Alejandrino admite el conocimiento natural y lo extiende y profundiza hasta admitir un quid divinum dentro del hombre, adoptando en ese sentido muchas expresiones platónicas ${ }^{76}$. El proceso platónico (agnóia, conversión-epistrophé, iluminación, gnosis, visión o unión) es acogido para explicar el progreso espiritual del alma como regreso a Dios. Veremos a Dios por el Logos ${ }^{77}$. El Logos es la imagen de Dios y nosotros somos la imagen del Logos, como en Filón. Imagen significa aquí copia, impresión, sello de la gnósis, deificación. La gnosis es el instrumento o método de restauración de la imagen y por esa gnosis llegaremos a ver a Dios 78 . El vocabulario de la gnósis filosófica, que Clemente utiliza mucho, nos indica que admite fácilmente la imagen de Dios, natural, y la imagen sobrenatural, que se nos da con el bautismo. Ambas corresponden a las dos formas de sofía, la natural y la sobrenatural. Logos y Sofía quedan casi identificados según la tradición alejandrina. La coincidencia con Filón, casi en todo, obliga a dar la misma interpretación. La imagen sobrenatural es el Espíritu Santo que convierte al cristiano en pneumático.

No hay que olvidar el ambiente pagano que rodeaba a los cristianos. Clemente denuncia las pinturas y estatuas obscenas que aparecen en todas partes, esas "imágenes" de los dioses que son en realidad imágenes del pecado y de la deshonestidad. A toda esa inundación de pornografía opone Clemente la ima-

75. Jenkinson, O. c., 64 s.; R.rM. Wmson, "The early History of the exegesis of Gen. 1, 26": Studia patristica. Berlín, I, 420-437.

76. No insiste tanto en el punto de la imagen natural, poraue sus escritos tienden a atraer a los paganos al Cristianismo. Por eso la "iluminación" comienza propiamente con el bautismo; sin embargo, su postura es paralela a la de Filón y a la de los Herméticos, y, por ende, hay que presuponer siempre la imagen natural.

77 Cfr. A. Whosor, Laktánz und die phitosophische Gnosis. Heidelberg 1960 , 147. Como en Filón hay en Clemente una doble iluminación, la de la Lev y la del Logos (Strom. VII, 16,6). Pero Cristo es pára él, al mismo tiempo, el Logos y el Nomos, acogiéndose a un texto de Is. 2. 3: De Sion exibit Lex (Nomos) et Verbum (Logos) Domini de Jerusalem. El concento de iluminación se aplicaba al bautismo desde el principio, como se ve en San Pablo.

78 "Imagen (eikón) de Dios es el Logos... imagłon del Logos es el hombre verdadlero, el nous diel hombre, por el aue se dice aue el hombre foe constituído según la imagen y la semejanza" (Protrépitico, 98, 4). "Imagen de Dios es el Logos divino... imagen de la imagen (eikón dè eikónos, anthropinos nous') es la inteligencia humana" (Strom. V, 94, 3 ss.). El "gnóstico" es. pues. una copia del Logos, porque recibe en sí el "sello" de la gnósis (Strom. I, 35, 1), y do ese modo "restaura la imagen divina" (Strom. III, 42, 6). La imagen es "sello" y "carácter" divino (Strom. II, 97, 1). 
gen íntima de Dios, huésped, consejera, comprometida, consorte nuestra, que nos convierte en víctimas (Anathema) consagradas a Cristo y en familia de Dios ${ }^{79}$. Tanto en Clemente, como en Orígenes, Tertuliano y el Crisóstomo, es fácil ver cómo oponen a la profusión de pinturas, estatuas e imágenes del paganismo, la sobriedad judía y cristiana, que apenas admite imágenes de Dios, y que insiste en la imagen interior, viva y verdadera, que es el mismo hombre ${ }^{80}$.

Según Clemente, Dios hizo al hombre a su imagen por la misma creación, pero luego lo perfeccionó, y de este modo se aplica al Génesis el platonismo, bajo la influencia de Filón. La "semejanza" es, pues, algo que se va añadiendo a la imagen fundamental ${ }^{81}$. Entiende que Adán fue creado apto para ir recibiendo las perfecciones que le asemejaran a Dios hasta ser pneumático, perfecto, santo conforme al nous. La imagen es, pues, potencialidad, mientras que semejanza es realidad, gnósis. El bautismo es equiparado a la "iniciación" en los misterios: es sello y carácter, energía divina, luz inteligible y transformante, que restaura la imagen. En otros pasajes la imagen corresponde al telos platónico: semejanza con Dios, que no se pierde, pero que se crece ${ }^{82}$

La clave para interpretar a estos alejandrinos es siempre la doctrina socrática del daimon, parte principal o preciosa del alma, que hemos de salvar ${ }^{83}$. Y la salvamos aplicándole o imprimiéndole la forma o carácter, que es Cristo: por la imitación llegamos a ser "dioses" 84 .

Orígenes continúa la dirección de Clemente, pero con mejor conocimiento de la Biblia. La aceptación del daimon le coloca en postura ambigua, ya que

79 Clemente Alej., Cohortatio ad Gentes, 4, PG. 8, 158 s.

80 Ibid. 161: "Nos enim clare prohibemur fallacem hanc artem (picturam) exercere: non facies enim, inquit propheta, cuiusvis rei similitudinem... Sed vos quidem in id omnem vestram curam atque studium impenditis, ut statua fiat quam pulcherrima...".

81 "Ad imaginem quidem statim in ortu accepisse hominem; ad similitudinem autem, per perfectionem postea esse accepturum" (Stromatum, II, 22, PG. 8, 1.079 s.). Clemente confiesa su dependencia de Platón y de Filón (Stromatum, II, 19, PG. 8, 1.043 s.).

82 La hermosura de la actitud de Clemente proviene del fuerte contraste con el paganismo, con los misterios y con la gnosis herética. Por eso no se detiene tanto en la imagen "natural", ya que para él la naturaleza no es casi nada: nos describe a Adán casi como un animalito bello y libre ("Primus homo olim paradisum incolens, ludebat solutus, quia puerulus erat Dei". Cohortatio ad Gentes, 11, PG. 8, 227). Se detiene en la imagen sobrenatural (Ibid. 12. PG. 8; 246). La escuela alejandrina anuló a los gnósticos heréticos', al arrebatarles todo lo que tenían de bueno, incluída la teoría de la imagen.

83 "Plato dicit beatitudinem, auae est audaimonía, esse bene habere daemonem; dicit autem daemonem, principalem animae nostrae partem; beatitudinem autem esse perfectissimum bonum et plenissimum... Sic quidem ex nositris illud ad imaginem et similitudinem..." (Stromatum, II, 22, PG. 8. 1.079). Clemente identifica la eudaimonía platónica con la justicia $0^{\prime}$ santidad bíblica (Ibid.). Por eso Cristo es el Modelo, aue tenemos que imitar nara ser imágenes de Dios (Paedaqoai, I, 12, PG. 8, 371). Cristo, el Verbo, es la "Faz" de Dios (Ibid. 7, PG. 8, 319).

84. ID. Paedagogi, I, 12, PG. 8, 367. 
parere tener algo de "divino", aunque establece que la imagen propia de Dios es sólo el Logos ${ }^{85}$. El hombre fue hecho a imagen de Dios; pero en cuanto a la semejanza, tiene que conseguirla el hombre como en Clemente Alejandrino ${ }^{86}$. Distingue, pues, dos imágenes diferentes: la que Adán perdió con el pecado, y la que conserva el hombre terreno. La imagen perdida o "sobrenatural" nos es devuelta en el bautismo: es participación en la naturaleza divina e implica también semejanza moral o santidad. Cristo, al encarnar, se hizo "imagen del hombre" como en Clemente Alejandrino; al imitarlo nosotros a $\mathrm{El}$, nos hacemos imágenes de El, de Dios. Cristo participa de Dios como Hijo: es, pues, imagen propia. Nosotros participamos como una estatua o pintura: somos imágenes impropias ${ }^{87}$. Pero adquiriendo la semejanza, podemos llegar a una suerte de deificación ${ }^{88}$. Es natural que se sienta la tentación de equiparar a Orígenes con San Agustín. No se olvide, sin embargo, que son dos mundos diferentes.

Hemos recibido de Dios el daimon, la imagen, como un depósito, que debíamos conservar y abrillantar; pero lo perdimos o deterioramos por el pecado y tenemos que restaurarlo por el bautismo y por la ascesis ${ }^{89}$. Hermosa es la metáfora del dracma de la parábola, aplicada por Orígenes a la imagen, y que nos hace pensar en San Agustín ${ }^{90}$. El Padre dice al Hijo: Hagamos al hombre. $\mathrm{Y}$ el Hijo es el pintor de la imagen, que perdura siempre, aunque deteriorada ${ }^{91}$.

Podríamos multiplicar los textos y ordenar una teoría completa y múltiple de la imagen en Orígenes, pero no es este nuestro intento. A pesar de su riqueza maravillosa, tenemos que advertir que esa misma riqueza daña no poco a la teoría, por su complejidad, frecuentemente ocasional. Tenemos que advertir además que tanto la imagen natural como la sobrenatural son concebidas a la

85 ORÍGenes, Perí Archôn, I, 2, 4-9, PG. 11, 133-138.

86 ID. O.c., III, 6, 1, PG. 11, 333; C. Celisum. IV, 29 ss., PG. 11, 1.070-1.074

87 La imagen natural es la parte más preciosa e íntima del alma: "Cum in anima, non in corpore, impressus sit imaginis Conditoris character" $(C$. Celsum, VIII, 49, PG. 11, 1.590).

'88 "Mens quae Dei capax est... semped tamen habeat in se velut semina quaedam reparandi ac renovandi melioris intellectus, cum ad imaginem et similitudinem Dei... renovatur" (Perí Archôn, IV, 36. ś., PG. 11, 412).

89 "Animae tuae Deus imaginem suam et similitudinem commendavit... Abjecta imagine Dei, diaboli in te imaginem suscenisti, et bonum depositum abnegasti... Si perfectus' es, sicut Pater tuus in coelis perfectus est, imaginis Dei in te depositum manet" (In Levit, Hom. IV, 3, PG. 12, 436).

90 "In lumine ejus' videas lumen, invenies' intra te drachmam. Intra te namque collocata est imago regis coelestis" (In Genesim, Hom. XIII, 4, PG. 12, $234)$.

91 "Haec imago est de oua dicebat Pater ad Filium: "Faciamus hominem ad imaginem et similitudinem nostram". Filius Dei est pictor hujus imaginis. Et quia talis ac tantus est pictor, imago ejus obscurari per incuriam potest. deleri per malitiam non potest. Manet enim semper imago Dei in te, licet tu tibi ipse superducas imaginem terreni..." (1. c.). 
manera griega, como potencias que pasan al acto ${ }^{92}$ y se desarrollan con la gnosis ${ }^{93}$.

Después de Orígenes se acentúa la distinción entre imagen y semejanza, para exponer la imagen según el Nuevo Testamento. Metodio de Olimpia prefiere volver a Ireneo, en lugar de seguir a la escuela alejandrina. El hombre es naturalmente imagen de Dios por ser racional y libre. La imagen corresponde, pues, a la creación, mientras que la semejanza es la que corresponde a la corrupción por el pecado y a la restauración por Cristo ${ }^{94}$. En cambio, Atanasio va al extremo contrario: parece admitir sólo la imagen sobrenatural, que es al mismo tiempo semejanza, resultado de la inhabitación del Logos en el alma. Por ende, Adán fue creado en el paraíso, en la contemplación de Dios ${ }^{95}$. El pecado consistió en desdeñar la contemplación de Dios para contemplarse a sí mismo ${ }^{96}$. Así nació la malicia (kakía), primera causa de la idolatría 97?. Es, pues, claro que Atanasio continúa las teorías de Clemente Alejandrino ${ }^{98}$. Dios creó al hombre a su imagen y semejanza y el pecado deterioró la imagen; cuando la imagen es restaurada, vuelve a ser "pura e íntegra imagen" del Verbo, espejo del Padre. Así como a Fidias se le podía descubrir por sus estatuas, así también a Dios se le puede descubrir por su obra maestra, que es el alma humana.

92 "Intuens imaginem (Verbum), per Verbum et virtutem ejus recipiet formam illam quae data ei fuerat per naturam..." (In Genesim, Hom. I, 13, PG. 12, 157; In Matth. tom. X, 10 s., PG. 13, 858 s.). La tendencia esteticista y artística, que era ya muy fuerte en Clemente, lo es también en Orígenes. Las teorías miméticas helenistas, sobre todo las de Aristóteles, son aplicadas a este tema con toda libertad. Cristo es el dechado: el hombre va copiando sus rasgos (In Lucam, Hom. VIII, PG. 13, 1.820).

9|3 Por eso el fundamento de la teoría de la imagen es siempre el Logos (In Jo. tom. II, 2, PG. 14, 110; In Ep. ad Rom. lib. VII, 6-8, PG. 14, 1.120-1.125; In Genesim, Hom. L, 13, PG. 12, 155 s.; C. Celsum, IV, 30 y 85, PG. 11, 1.071 y 1.159; Perí Archôn, III, 6, 1, PG. 11, 232 s.). Cfr. J. Dantelou, Origène, París 1948, 291; E.-C. PUECH, "Mystique d'Origène": Rév. hist. phil. relig. 13 (1933) 327 ss.; J. STELzenBerger, Synédesis bei Origenes, Paderborn 1963, especialmente $39-45$. Orígrenes ofrece algunas dificultades por razón de sus fuentes, especialmente en el caso de Platón y Filón. Cifr. F.-H. KETTLER, Der ursprüngtiche Sinn der Dogmatik des Origenes. Berlín 1966, 26-30.

9.4 "Hominem, rationalem Dei effigiem" (Merodio, Convivium decem Virg. VI, PG. 18; 55 s.; VII, PG. 18, 58; De libero Arbitrio, PG. 18, 259). El hombre es una estatua labrada por Dios, deteriorada por el pecado, restaurada por el cristianismo (De Resurrectione, VI, PG. 18, 271; 10, PG. 18, 278; 15 у 16, PG. 18, 287, 288).

95 Atanasio, C. Gentes, 2 ss., PG. 25, 7 ss.

96 ID. C. Gentes, 3, PG. 25, 7 s.s.

97 "Sic autem a vero aversa, et. se ad imaginem boni Dei factam essie oblita, non amplius Deum Verbum, ad cujus similitudinem creata est, sua facultate videt... Prima ergo idololatriae causa est malitia" (C. Gentes, 8, PG. 25, 15-18). En esta obra se mantiene la misma postura de Clemente Alejandrino, por oposición a la pornografía pagana (C. Gentes, 33, PG. 25, 67).

98 "Patris Verbum, ad cujus similitudinem ab initio facti sunt, in illa intueri valeant. Ad imaginem siquidem et similitudinem Dei facta et creata est anima... Quocirca, cum omnes peccati maculas abstersierit, et similitudinem integram servaverit... comprehendet" (C. Gentes, 34, PG. 25, 67-70). 
Cuando Atanasio va delineando esta teología del Logos, piensa ya en una refutación del arrianismo, puesto que ya comienza a pensar que el "faciamus" del Génesis implica pluralidad de personas, pero dentro de una sola naturaleza. ¿Con quién habla Dios? Con el Verbo. Este es la Sabiduría, presente en la creación del mundo. $\mathrm{Y}$ puesto que el hombre es creado "ad imaginem et similitudinem nostram", ya tenemos a la vista la consustancialidad del Verbo con el Padre ${ }^{99}$. Así Atanasio aprovecha la doctrina de la imagen para aplicarla a una nueva situación dogmática ${ }^{100}$. Queda de nuevo la Sabiduría Intermediaria como exégesis del hombre creado a imagen y semejanza de Dios, como Creador y no como criatura ${ }^{101}$. Es indudable la grandeza que adquiere de este modo la doctrina ${ }^{102}$. La razón de esta grandeza es que Atanasio mantiene más puro el sentido bíblico y considera la economía soteriológica como "historia de la salvación" 103. Dentro de esta síntesis se explica ahora la fórmula mística in ipso vivimus ${ }^{104}$. Pero también se explica dentro de esa síntesis la conveniencia de que el Verbo se hiciese "carne", cuerpo, para remediar la situación miserable del hombre y continuar su intermediación soteriológica ${ }^{105}$. En adelante, los demás Padres combinan todas estas nociones.

Los Padres capadocios no ofrecen novedad alguna. La imagen natural pasa al segundo plano oscuro, y la imagen sobrenatural es la que merece su solicitud atenta. San Basilio nos explica cómo Adán perdió la deificación, que se recobra por Cristo y el Espíritu Santo ${ }^{106}$. San Gregorio Nacianceno habla del Nous, pero viene a repetir lo mismo ${ }^{107}$. En fin, San Gregorio de Nyssa nos abruma con su erudición, pero no hallamos en él una postura neta y firme. Por un lado, parece aceptar la tradición alejandrina; por otro, parece denunciar algunas exageraciones que por ese camino había cometido Eunomio. Por un lado, parece renunciar al intelectualismo, buscando, como Plotino, la unión mística con Dios por medio del amor; pero, por otro lado, insiste en una gnósis, en una theoría y epópteia. Por otra parte, la unión con Dios se realiza con la intervención del Logos. El

\footnotetext{
99 Ibid. 46, PG. 25, 94.

100 "Necesse sit Verbum in genitore, et genitum cum Patre perpetuo permanere" (Ibid. 47, PG. 25, 94).

101 ID. C. Amrianos, II, 70, PG. 26, 295.

102 Cfr., como ejempilo, la hermosa síntesis en De Incarn. Verbi, 12-14, PG. 25, 115-119.

103 Ibid. Así recibe el platonismo un fuerte contrapeso.

104 Ibid. 42, PG. 25, 170.

105 Ibid. 45, PG. 25, 175-179.

106 Basmio, De Spiritu Sancto, 9, 23, PG. 32, 110; Ibid. 18, 45, PG. 32, 150 s.; ID. Ep. 233, 1-3, PG. 32, 863-867. Es muy útil San Basilio para estudiar la obra del Espíritu Santo en la asimilación del alma a Dios (Die Spiritu Sancto, 9, 23. PG. 32, 110; Ep. 9, 1-3, PG. 32, 267-271; Adversus Eunomium; V, PG. 29, 723-731).

107 Gregorio Nacianceno, Oratio, 39, 13, PG. 36, 347 ss.; Ibid. 1, 4 s., PG. 35, 398 s.; Ibid. 38, 11, PG. 36, 322; Ibid. 8, 6, PG. 35, 795. Propone una imagen de la Trinidad: mens-sermo-spiritus (Ibid. 23, 11, PG. 35, 1.163).
} 
Logos es la Imagen del Padre, el Mediador, y el hombre es imagen del Logos, como en los alejandrinos. Imagen y semejanza son para él sinónimos, y entonces la imagen implica todo género de semejanzas del hombre con Dios naturales o sobrenaturales, excluyéndose tan sólo la vida animal, que según él no entra en la específica "naturaleza" humana. Al dar a la imagen un sentido sobrenatural muy marcado, la viene a identificar con lo que nosotros llamamos la gracia santificante. En suma, Gregorio recoge de la tradición filosófica y eclesiástica muchas doctrinas, pero al fundir el platonismo con el filonismo y los textos bíblicos, resulta la ambigüedad, porque la imagen lo es todo, y no se puede definir concretamente qué es. A veces, parece distinguir entre imagen y semejanza; a veces, parece que se trata de dos aspectos diferentes de una sola realidad: la imagen sería el aspecto estático y la semejanza sería el aspecto dinámico: la omóiosis sería realización progresiva del eikón: volvemos a los alejandrinos, pero en el orden sobrenatural y así nos oponemos a Ireneo ${ }^{108}$.

San Cirilo defiende la imagen y semejanza como don del Espíritu Santo y así vuelve a San Ireneo. Pero esa imagen está en el alma y no en el cuerpo, lo mismo que en Orígenes. Por lo tanto, la imagen es en principio la ratio, y a veces la libertad o la inmortalidad. Siendo don del Espíritu Santo, se explica que los patriarcas y Profetas participasen de ese Espíritu Santo, que "Dios sopló sobre el rostro de Adán" 109! La redención de Cristo consiste cabalmente en la restauración de la imagen ${ }^{110}$.

San Epifanio, espantado por tantas opiniones, se siente escéptico acerca de la interpretación auténtica. Admite fácilmente que el hombre fue creado a imagen y semejanza de Dios, puesto que lo dice la Biblia, pero se niega a aceptar las opiniones humanas acerca de la consistencia de esa imagen. En principio,

108 De todos modos, Gregorio Niseno pone de gran relieve la importancia de este tema, dedicándole un cuidado muy atento y entusiasta. Cfr. Gregorio Nrseno, De Imagine Dei, PG. 44, 1.327-1.346. Ya comienza a distinguir las opiniones: según unos, la imagen es la facultad de imperar; según otros, la espiritualidad e invisibilidad del alma; según otros, la incorruptibilidiad e inocencia; según otros es el bautismo, proféticamente anunciado (1. c.). El se atreve a proponer que quizá la imagen se refiere al Verbo en cuanto Dios y la semejanza a Cristo en cuanto hombre (1. c.). Se remite a Metodio do Olimpia (1. c.). Se propone buscar semejanzas para estudiar la Trinidad por las analogías humanas. Pero la maraña de las discusiones con Arrio y con Eunomio no le permite desenredar una madeja tan confusa. El principio, sin embargo, servirá a sus sucesores y especialmente a San Agustín. Cfr. J. DANIELou; Platomisme et Théologie mystique, Aubier 1944.

109 Cuando distingue la imagen de la semejanza, la imagen consiste en la naturaleza y la semejanza en la virtud. Cfr. CIrILo, Catechesis, IV, 18, PG. 33, 478 ss.; Catech. XII, 5, PG. 33, 731; Catech. XIV, 10, PG. 33, 835 ss.; cfr., en cambio, Catech. XVII, 12, PG. 33, 983 s's.

110 Ibid. Por eso mismo, no aparece clara la distinción entre la infusión. inicial del Espíritu Santo en el baútismo y la progresiva y ulterior semejanza que se va lograndio con la virtud $\mathrm{y}$ con la ascesis (Catech. XVII, 14, PG. 33, 986; Catech. XXI, 1 ss., PG. 33, 1.087 s.). 
advirtiendo que todas las opiniones son dudosas y aun falsas, recoge a título informativo cinco opiniones:

1. La imagen de Dios está en el cuerpo. Así lo creen Audiano, Melitón de Sardes, Lactancio y los estoicos. Se trata de la figura erecta y de la vista adelante y hacia lo alto, según el argumento apologético de los sofistas.

2. La imagen está en el alma. Así lo creen Gregorio de Nisa, Eucheiro y casi todos los autores influídos por el platonismo. Perc la imagen queda entonces mal definida y vaga. Lo abarca todo, según los diferentes autores, pero no se define como potencia concreta y determinada al gusto helenista.

3. Consiste en la semejanza o virtud moral: Así Orígenes, Procopio de Gaza, etc.

4. Consiste en la gracia, en una facultad sobrenatural que' recibimos en el bautismo y vamos luego desarrollando : así Ireneo, Orígenes...

5. Consiste en la vida sobrenatural, que recibimos cón la gracia, pero sin que se pueda señalar una propiedad concreta: es algo que se perdió con el pecado y se recobra con la gracia: así el Crisóstomo, etc.

Pero luego San Epifanio añade otras dos:

6. Consistiría en el dominio sobre la tierra, sobre los animales, en conformidad con el texto del Génesis.

7. Consistiría en la libertad perfecta, que se perdió con el pecado y se recobra con Cristo y con la progresiva ascesis.

No se agotan todavía las opiniones:

8. Podría consistir en que el hombre pertenece a dos mundos, al sensible y al espiritual, tales como Dios los creó: así lo defiende Teodoro de Mopsuestia.

9. Podría formarse la imagen por un conglomerado de propiedades y potencias de todo género, pero diferentes de las enumeradas por San Gregorio de Nisa: el hombre abarca lo visible y lo invisible; domina a los animales; es deminurgo; es señor y juez; tiene nous, intelecto; es trino, compuesto de nous, logos y pneuma: así Teodoreto de Ciro.

10. Podrían hacerse recuentos diferentes. El hombre tiene providencia; el alma es invisible e inmortal; representa a Dios, dominando en la tierra, como Dios domina en el Cielo, etc.: así Genadio de Constantinopla ${ }^{111}$.

La postura de San Epifanio nos está indicando que tantas opiniones habían sembrado el escepticismo sobre la imagen: ésta lo es todo y no es nada. Así, San Epifanio, rechazando unas opiniones por demasiado vagas, otras por demasiado concretas, otras por falta de lógica, otras por contradecir a algún texto bíblico, otras porque son incompatibles con la situación de pecado de Adán o de justicia del cristiano, etc., y declarando paladinamente que lo único que pode-

111 Cfr. PG. 50, 900 s. Recuentos semeiantes podemos verlos en Proconio de Gaza y en Anastasio del Sinaí. Cfr. PG. 87, 1, 120. 
mos afirmar es que Dios hizo al hombre a su imagen, porque lo dice la Biblia, es una prueba de ese mismo escepticismo que experimentaban los lectores.

Modernamente la afición al estudio de los Padres Griegos exige que seamos muy cautos en la interpretación. Su mentalidad era muy diferente de la mentalidad semita que hallamos en la Biblia y muchos de ellos habían estudiado filosofía helénica. Sus fuentes eran a veces profanas y con las fuentes daban, consciente $o$ inconscientemente, sentidos helenistas, que saben a naturalismo y a simple paso de la potencia al acto, a filosofía. Sus metáforas son arraigadas y nos dejan perplejos, a la hora de darles un sentido concreto. Cuatro son las metáforas principales que utilizan:

1. Si la imagen consiste en la gracia, Dios la imprime en el alma, como se imprime un sello. Tenemos entonces una causalidad formal, ya que el sello comunica una semejanza.

2. El Espíritu Santo es un artista, pintor, escultor, grabador: reproduce su propia imagen en el alma, dándose, aplicándose a Sí mismo. Tenemos entonces la misma causalidad formal.

3. El Espíritu Santo unge al alma con un óleo, que es El mismo. Es una exégesis de Rom. 5, 5, pero con el riesgo de reducir la interpretación a un sentido helenista.

4. El Espíritu Santo impregna al alma de Sí mismo, como si fuese un perfume sagrado. $\mathrm{Y}$ nos ocurre entonces lo mismo.

Zubiri, al darnos un estudio rápido sobre el ser sobrenatural en la teología griega ${ }^{113}$, nos da también una radical diferencia: "la teología griega considera al hombre como un trozo de la creación, del cosmos". Para Zubiri eso es quizá una ventaja; para otros será una gran desventaja, ya que el hombre no es un trozo del cosmos, sino un "esfíritu". Eso no significa negar los inmensos tesoros doctrinales que se encierran en los Padres Griegos, sino recordar que, al fin y al cabo, eran griegos: nuestras interpretaciones occidentales de los griegos corren el riesgo de proyectar sobre ellos el espíritu latino, y entonces ocurren cosas sorprendentes e imprevistas. Zubiri, al estudiar la relación del griego eikón con el latino imago, advierte: "no olvidemos la diferencia profunda de esta noción griega de eikón con la latina imago. La imago es imagen, porque se parece a lo imaginado; pero el eikón se parese a lo imaginado porque procede de él. Las propiedades de las cosas y sus efectos son en este sentido eikonal similitudo,

112 Cfr. H.-M. SchenKe, Der Gott-Mensch in der Gnosis, Göttingen 1962, 135-139.

113 Cfr. X. ZubIRI, Naturaleza, Historia, Dios, Madrid 1944, 472. Zubiri añade: "El pecado, para un latino, es ante todo una malicia de la voluntad; para el griego, ess sobre todo una mácula de la creación. Para el latino, el amor es una aspiración del alma, adscrita preferentemente a la voluntad; para el griego es, en cambio, el fondo metafísico de toda actividad, porque esencialmente todo ser tiende a la perfección...". 
imago ac derivatio, que nada tienen que ver con el ejemplarismo occidental" 114 . Está clara la relación del eikón con un fundamento que Zubiri llama procedencia o derivación, pero que en el fondo responde al concepto griego de generación. Y esto está muy bien para explicar el Logos. En cuanto a la explicación del eikón humano, ahí está el problema del espíritu, que es misterio cabalmente porque no es un trozo del cosmos, porque no se puede explicar en un capítulo De generatione et corruptione, sino en un capítulo De creatione: y la creación es una noción semita, que es otto misterio; la dialéctica griega tiene que tener mucha paciencia con los semitas y los latinos.

Es cierto que, puesto que los Padres Griegos se mantienen dentro de la misma ortodoxia que los latinos, serán siempre para la Iglesia una fuente riquísima de doctrinas y de sugerencias. Pero eso no nos dispensará nunca de leerlos con las convenientes atenciones. De ese modo nos evitaremos quizá muchas situaciones irreconciliables y podremos saber con precisión qué es lo que dicen realmente los Padres Griegos. Muchos autores, siguiendo al P. Mauricio de la Taille, el cual a su vez se hacía eco de otros autores, sostienen que, según los Padres Griegos, Dios es la forma o cuasi forma de la imagen ${ }^{115}$. Otros autores, en cambio, rechazan enérgicamente esa interpretación, que al parecer va en contra de los presupuestos tomistas ${ }^{116}$. En realidad sacaríamos muy poco, si hiciésemos a los Padres Griegos tomistas o suarecianos. Ya hemos visto en qué perspectivas hay que colocar la imagen de Dios dentro de la Patrología griega, la cantidad de opiniones, la diversidad de sentidos, la multiplicidad de fuentes e inspiraciones. Toda esa riqueza puede sernos muy útil. Pero no podemos reducirla a una sola noción, ni imponer una sola interpretación, ni creer que la interpretación "helenista" habrá de sobreponerse nunca a la interpretación semita o latina de la Biblia.

La riqueza del Evangelio dependerá en gran parte de la interpretación que se le dé. Y la interpretación irá cambiando según la cultura reinante en cada época. El paso de una iglesia judía a una iglesia helenista tuvo sus riesgos, y tuvo sus innegables ventajas: sin embargo se mantenía la misma doctrina en diversas formas. El paso de una iglesia helenista a una iglesia latina no podía realizarse de otro modo. No era nínguna injuria para la iglesia griega el que los latinos entendieran el Evangelio a su manera. También Europa lo entendió a su manera y nosotros lo entendemos a la nuestra.

114 Ibid. $492 \mathrm{~s}$.

115 Cifr. R. GLEason, Grace, N. York 1962, $140 \mathrm{~s}$.

116 Cfr. Ch. KIESLING, "The divine Indwelling in R. W. Gleason's Grace" : The amer. eccl. rev. 150 (1964) 263-285. 
IX. LA IMAGEN EN LOS PADRES LATINOS.

Si suponemos que el paso de un helenismo a un latinismo fue semejante al paso de un semitismo a un helenismo, entenderemos bien a los Padres Latinos. Porque eso significa que no hay ningún cambio en la doctrina fundamental 117, por mucho que se quieran profundizar las diferencias. Pero eso significa al mismo tiempo que hay diferencias, y que esas diferencias pueden ser muy profundas ${ }^{118}$. Suele decirse que los Padres Latinos no hacen otra cosa que seguir a los griegos, y un poco a los clásicos latinos, los cuales siguen también a los clásicos griegos; de ese modo carecen de originalidad y de posturas realmente personales. Pero con eso no se ha dicho lo principal, ya que una actitud diferente ante el mundo y ante la vida tiene más importancia que las ideas concretas que un autor toma de otro, adaptándolo a su propio modo de ver. Esto es lo que acontece realmente con los Padres Latinos: tienen otro modo diferente de ver. Lo cual tiene mucha importancia, cuando se trata de interpretar una Biblia, que en definitiva no está escrita por griegos, aunque esté helenizada en mayor o menor grado en muchas partes. Es discutible entonces quien interpretará mejor esa Biblia semita. No había nacido aun el concepto de "autoridad" en el sentido de la "tradición", tal como lo vivió la Edad Media y lo vive la Moderna: los Padres Latinos se sentían estimulados y libres en su exégesis de la Biblia y como "Padres" tienen los dones de Dios tanto como los Padres Griegos. Es indudable que la comparación de un modo de ver con otros diferentes será en el futuro una fuente teológica: no tratemos de "reducir" los unos a los otros, sino de "compararlos".

Los Padres latinos insisten en la causalidad imperial o señorial. Tertuliano, hablando de la imagen de Dios, parece como que nos viene a decir que Dios es materia y que el alma humana es una porción material de $\operatorname{Dios}{ }^{119_{i}}$; $Y$ cuánto se ha discutido sobre el materialismo de Tertuliano! Pero no es lícito aplicarle normas que no sean suyas. Gennadio atribuyó sin más ni más a Tertuliano la sentencia de Platón, por esa frase ${ }^{120}$. Es necesario recurrir a aquellos lugares en que Tertuliano habla expresamente del origen del alma comentando Gen. 2, 7. $\mathrm{Y}$ entonces vemos que Tertuliano es todo lo contrario de Platón. Lo que Tertuliano quiere poner de relieve es que el alma no es emanación de Dios, no viene

117 Cfr. A. Turrado, "La Sma. Trinidad en la vida espiritual": Rev. d'études august. 5 (1959) 129-151, 223-260; ID. "Eil platonismo de San Agustín y su doctrina acerca de la inhabitación del Espíritu Santo": Augustiniana 5 (1955) 471-486.

118 Cfr. ZuBIRI, Naturaleza, Historia, Dios, Madrid 1944, 472.

119 Hominem redi jubet Creatori, in cujus imaine at similitudine et nomine et materia expressus est (TeRTuLiano, C. Marcionem, IV, 38, PL. 2, 453). *

120 Nihil ex Trinitatis essentia ad creaturamum naruram credamus deductum, ut Plato et Tertulianus (Gennadio, De Dogmat. Ecclies. 4, PL. 58, 982). 
de Dios en virtud de una ley, o de una naturaleza, o de un bien que al difundirse necesariamente con un movimiento interno y necesario produzca almas: quiere poner de relieve que el alma procede de una intervención extraordinaria, de un "milagro", de una acción libre de Dios, el cual sopló sobre el rostro de Adán: el alma nació de ese soplo. Ahora bien, el que el origen del alma venga de ese soplo no quiere decir que el alma sea el soplo, pues en ese caso Tertuliano volvería a recaer en lo que quiere impugnar. El término "origen" es ambiguo, porque en Grecia y en Roma la causalidad es diferente ${ }^{121}$. El alma inmortal y espiritual, que Tertuliano opone a los gnósticos no puede ser fruto de una ley, sino de una libertad.

A la misma conclusión llegamos, si relacionamos a Tertuliano con los estoicos a los que impugna, tomando las mismas doctrinas de ellos. Así, comienza admitiendo un conocimiento natural, un sentido común, un "alma naturalmente cristiana" "que no quiere conocer a quien no puede ignorar" y que la filosofía y la cultura y la sociedad entera se encargan de corromper. Pero luego coloca al estoicismo entre esas filosofías corruptoras del alma cristiana. Es la norma del famoso africano: partir de un punto común, para buscar luego su propio camino.

En la doctrina de la imagen, su punto de partida es el mismo de San Ireneo: aunque con frecuencia imagen y semejanza parecen sinónimos, llegando el caso, hay la misma diferencia que en San Ireneo, según vimos arriba; como en San Ireneo, Dios sopla sobre el rostro de Adán para infundirle un espíritu que es el Espíritu Santo. Adán lo pierde por su delito, pero el cristiano lo recobra en el bautismo. Ese bautismo significa algo más: una iluminación del alma, un sello del Logos para la reviviscencia y restauración de la imagen ${ }^{122}$. En todo esto no se aprecia la originalidad de Tertuliano, pues se halla en San Ireneo. Otras doctrinas concretas están tomadas de Filón, de la filosofía estoica, de la Biblia, y tampoco ofrecen originalidad alguna ${ }^{123}$.

La creación obedece a una orden libre y no a una difusión espontánea de la bondad divina. Tertuliano lo pone de relieve para distinguir al Padre del

121 Eso es lo que Tertulianio afirma contra Marción, el cual piensa como gnóstico griego: Adversus Hermogenem ex materia, non ex Dei flatu contendit, flatum proprie tuemur (De Anima, 11, PL. 2, 664). Riestaluitur homo ad similitudinem Dei, qui retrol ad imaginem D'ei fuerat: imago in effigie, similitudo in aeternitatie ciensetur. Recipit enim illum Deì spiritum, quem tunc de afflatu ejus acceperat, sed post amiserat per delictum (De Baptismo, 5, PL. 1, 1.206).

122 De Baptismo, 5 ss., ut supra; C. Marciomem, II, 4 y 9, PL. 2, 288 y 294. Cfr. IRENEO, De Haeres, III, 18 y 23, PG. 42, 435 y 445; F.-J. Dolger, "Sfragís": Studien z. geschichte u. Kultur d. Altert. 5 (1911) 3 ss.

123 De Test. Animae, 2, PL. 1, 612: Si enim anima aut divina, aut a Deo data est, sine dubio datorem suum novit (Ibid. 6, PL. 1, 617). Erat autem ad cujus imaginem faciebat: ad Fitii scilicet... imago veri es similitudo (Adv. Praxeam, 12, PL. 2, 168). 
Hijo. Dios Padre hace al hombre a la imagen del Hijo ${ }^{124}$. Esa postura se profundiza más al tener que discutir con los gnósticos la creación de la materia ${ }^{125}$. La imagen es aquí algo diferente, en cuanto depende de la voluntad de Dios, de un voluntarismo: es imagen "estampada" por orden de la Autoridad, es un sello imperial, de la oficina del Imperator divino. Por esto, no basta analizar las fuentes de Tertuliano: lo más importante es el modo cómo las utiliza, puesto que vive ya en un mundo no griego. Alguna vez parece contradecirse, al afirmar que la creación del hombre a imagen de Dios se debió, no a una orden imperial, sino a la pura bondad divina ${ }^{126}$. Pero el contexto mismo demuestra que no se trata de la bondad griega espontánea y difusiva, sino de la bondad imperial que, en lugar de lanzar un mandato, procede con modos amables y acariciadores: non imperiali verbo, sed familiari manu, etiam verbo blandiente prdemisso: faciamus bominem ad imaginem et similitudinem nostram. Bonitas dixit, bonitas finxit bominem... Bonitas inflavit animami.. Bonitas praefecit universis fruendis... Cabalmente, la lucha contra Marción le viene muy bien para acentuar el sentido de la "imagen": es imagen, pero muy distinta y diferente del original: imago veritati non adaequabitur. Aliud est enim secundum veritatem esse, aliud ipsam veritatem esse ${ }^{127}$.

Dios, pues, creó jussu et imperio et sola vocabuli potestate ${ }^{128}$; al hacer al hombre, El mismo tendió la mano para fabricarlo, por una condescendencia singular. Es el Padre el que dice, dirigiéndose al Hijo: "hagamos al hombre a nuestra imagen". Y entonces el Padre hace al hombre a imagen de Cristo ${ }^{129}$.

La postura de Tertuliano se hace paradójica, por vacilar entre el estoicismo y el cristianismo ${ }^{130}$.

Minucio Félix vuelve a los argumentos de los sofistas y de la tradición filosófica: la imagen de Dios consiste en la figura erecta y en la mirada hacia adelante, como dicen los estoicos ${ }^{131}$; pero además Dios nos ha dado la ratio y el

124. Dios crea al hombre a su imagen, pero por palabra, por voluntad: Christo assistente et adiministrante Deus voluit fieri, et Deus fecit... Habes duos, alium dicentem ut fiat, alium fqoientem... Eum qui jubet et eum qui facit (l. c.). La distinción entre el Padre y el Hijo sirve, pues, a Tertuliano, para afirmar que el Padre da la orden de ereación y el Hijo la ejecuta. De ese modo, nos separamos de la causalidad filosófica.

$125 A d v$. Hermogenem, 27, PL. 2, 221 s. No se trata de la mera fórmula: Nihil interest facta an nata sit abyssus, dum initium detur illi... (Ibid. 32, PL. 2, 227). No le engaña a Tertuliano su instinto, aunque no perciba, quizá, la diferencia radical.

126 C. Marcionem, II, 4, PL. 2, 288.

127 Ibid. 9, PL. 2, 295.

128 De Resurrect. Carnis, 5, PL. 2, 801.

129. Ibid. 6, PL. 2, 802 .

130: Apologeticum, 17, PL. 1, 371 ss.

131 Min. FelIX, Octavius, 17, PL. 3, 284 s. 
sermo. De ese modo se vuelve al argumento apologético: la misma estructura del hombre demuestra la existencia y providencia de Dios ${ }^{132}$.

Lactancio se inclina hacia los estoicos y pone la imagen de Dios en la vida y habilidad del hombre mismo ${ }^{133}$, en la figura erecta y en la mirada hacia adelante ${ }^{134}$. Pero entiende que eso se ordena a que el hombre conozca y sirva a Dios y de ese modo logre la vida bienaventurada: la imagen de Dios es, pues, la sabiduría y la virtud moral, que se reúnen en la religión cristiana. Lactancio se declara prácticamente escéptico y se refugia en la revelación; pero recurre a los filósofos para demostrar sus teorías. Toma la religión como "religo-religatio", suponiendo que nacemos con el conocimiento ínsito y natural, pero luego identifica ese conocimiento con la práctica religiosa y recurre al Timeo para demostrar la incognoscibilidad de Dios ${ }^{135}$. El hombre fue creado para conocer a Dios y sin embargo Dios es incognoscible: conocer a Dios es la piedad, la justicia, la religión. Acepta también la imagen sobrenatural que se inicia en el bautismo y se da con el Espíritu Santo en una nueva creación, coincidiendo en estos conceptos con San Cipriano ${ }^{136}$. En suma, para Lactancio la imagen de Dios consiste. en la figura erecta y la mirada hacia adelante, pero como símbolo de la actitud religiosa, que trata de salvar el alma con la prudencia y la piedad ${ }^{137}$.

La misma postura de Tertuliano hallamos en Novaciano: el hombre es imagen de Dios en cuanto al alma, pero la imagen campea por su libertad y responsabilidad ${ }^{138}$. Lo mismo que en el caso de Tertuliano, la doctrina viene de los alejandrinos y de Ireneo, pues se dice expresamente que la imagen de Dios es Cristo y que el hombre es imagen de la imagen ${ }^{139}$ : Pero, como en el caso de Tertuliano, el Padre da la orden imperial y el Hijo la ejecuta ${ }^{140}$. Finalmente, como Tertuliano y como Lactancio, muestra sus resabios escépticos, puesto que la imagen de Dios no sirve para ver a Dios, sino para servirle con la piedad y la religión.

132 Ibid.

133 Simulacrum Dei... est ipse homo (Inst. Div. II, 2, PL. 6, 260.

134 Inst. Div. VII, 5, PL. 6, 750.

135 De ira Dei, I, 6 ss., PL. 7, 92-98; Ibid. 10, PL. 7, 100-104; Inst. Div. II, 3, PL. 6, 265 ss.; Epitome, 32, PL. 6, 1.039; Ibid. 23, PL. 6, 1.030.

136 Inst. Div. III, 26, PLi. 6, 431.

137 Cfr. A. WLOSOK, Laktanz und die philosophisiche Gnosis, Heidelberg $1960,180-222$.

138 Hominem mundo praeposuit, ad imaginem Dei factum: cui mentem et rationem indidit et prudemtiam, ut Deum posset imilari... Salum liberum esse voluit. Et ne in periculum caideret rursum soluta libertas, mandatum posuit... Nam et liber esse debueriat, ne incongruenter Dei imago serviret, et lex addienda, ne... (Novaciano, De Trinitate, 1, PI. 3, 887 s.).

139 Christus, in imagine Dei... Hominem enim scimus ad imaginem, non ad formam Dei factum (Ibid. 22, PL. 3, 929).

140 Faciamus hominem... Deo praecipiente ut homo fiat... Facit autem hominem Dei Filius (Ibid. 17, PL. 3, 917). 
Con las mismas características se nos presenta San Hilario. Animado también él con las doctrinas estoicas, da un testimonio elocuente sobre el "instinto natural" del hombre, que podía servirle perfectamente para concretar la imagen de Dios: "El alma tiene sed de Dios, en quien está la fuente de la vida, alentada por la codicia de beber. En efecto, la mente de toda persona es llevada por un cierto instinto natural al conocimiento y a la esperanza de la eternidad. Todos llevamos ínsita e impresa la opinión de que el origen de las almas es divino, puesto que la mente reconoce en sí misma un no pequeño parentesco con el linaje celestial" ${ }^{141}$. El parentesco del hombre con Dios es explicado al modo de Filón. En efecto, se propone el texto Gen. 1, 26 como creación del alma, no del cuerpo; el alma fue creada a imagen de Dios, al modo de Filón. Sólo en el texto Gen. 2, 7 se habla de la creación del hombre terreno y empírico, cuando Dios insufla su espíritu. La imagen de Dios en el alma consiste en una semejanza de espíritus por la que el alma es racional, móvil, activa, ligera, incorpórea, sutil y eterna". Eso es "imitar la especie de la Naturaleza Principal" 142. De ese modo la renovación de la imagen de que nos habla Col. 3, 9 s. se verifica por esos rasgos fundamentales de la imagen. Marca así Hilario la diferencia que existe entre el hombre y el resto de la creación: Differt itaque natura et origo bominis ab institutione universae creationis ${ }^{143}$. Para la creación del hombre tenemos primero el consejo y el imperio de la Trinidad beatísima; y luego tenemos el privilegio de que Dios lo formase con sus divinas manos. La imagen de Dios es siempre Cristo, mientras que el hombre es "a imagen", imagen de la imagen ${ }^{144}$. Son, pues, tres los momentos de la imagen, al modo de Filón: primero, Dios crea al alma a su imagen y semejanza; segundo, Dios forma con sus manos el cuerpo humano; tercero, Dios insulla su Espíritu, entregando así el alma al cuerpo ${ }^{145}$. El hombre prevaricó, pero siempre conserva como una memoria oscura de su estado original ${ }^{146}$. Sin embargo, al pensar en la renovación cristiana de la imagen, cree como los otros Padres: que la imagen era una semejanza espiritual, que se perdió con el pecado original ${ }^{1} 47$; y de ese modo se mantiene la ambigüedad.

También aprovecha Hilario el "faciamus bominem" para demostrar la divinidad del Hijo ${ }^{148}$. Pero esa doctrina, recogida de la tradición, la aplica en el

\footnotetext{
141 In Ps. 62, 3, PL. 9, 402.

142 In Ps. 129, 5-7, PL. 9, 721; In Ps. 118, X, 2-8, PL. 9, 564-566.

143 In Ps. 134, 14, PL. 9, 759.

144 Ibid. 7, 566; De Trinit. III, 18, PL. 10, 86 y 92; VII, 37, 239 s.

145 Ibid. 8, 567; In Ps. 118, PL. 10, 635.

146 Talis igitur esse meditatur, qualis ille qui a Deo factus est, fuit ante peccatum. Per quod quia non mortuus saleculi, seid tamquarm mortuus saeculi in obscuris est collocatus, meditabitur sempier... antiquorum dierum memor... (In Ps. 142, 6, PL. 10, 839 s.).

147 In Ps. 150, 2, PL. 10, 890; In Ps. 149, 3, PL. 10, 886.

148 De Trinit. IV, 17, PL. 10, 110 y 135.
} 
mismo sentido de la tradición: Dios hizo al hombre a imagen de su Hijo, pues el crear en el Hijo y por el Hijo es lo que define a la imagen ${ }^{149}$. De todos modos, aunque en Hilario no hallemos originalidad, vemos cómo la controversia arriana obligaba ya a distinguir entre imagen y semejanza, ya que era peligroso afirmar que el Hijo es "semejante" al Padre cuando es homoousios: imagen es, pues, más propio y concreto que semejanza ${ }^{150}$. La teoría de la imagen se convierte así en argumento contra los arrianos. Con eso se desvirtúa el texto del Génesis, puesto que el hombre no es ya imagen de Dios: se dice "a imagen de Dios" para aducir un "ejemplo", lo que hoy llamaríamos una analogía, que consiste en que el alma humana es inmaterial y racional ${ }^{151}$. Hay, pues, una imagen natural, que consiste en la inmaterialidad y racionalidad del alma; y hay una imagen sobrenatural, que Adán perdió con el pecado y que se recobra con el bautismo; esta segunda imagen sobrenatural no sólo queda sencillamente recobrada, sino que luego tiene la misión de perfeccionar y consumar a la primera imagen, que con el mismo pecado de Adán quedó deteriorada. $\mathrm{Y}$ esta postura de Hilario es más rica y profunda 152 .

El caso de San Ambrosio es complicado. Por un lado, se tiende a negarle toda originalidad, alegando que copia de Orígenes, Filón y de los Padres Capadocios. Por otro lado, se tiende a poner de relieve la ambigüedad que produce la variedad de sus fuentes. Todavía se tiende a destacar su carácter romano; su nuevo espíritu. En suma, de un modo u otro, hay que pensar en una originalidad. Es, por de pronto, claro su voluntarismo, del que parte. Desde el principio se enfrenta con la doctrina del Logos, para rechazar el sentido platónico del mismo: Dios creó, no porque se viese platónicamente obligado a formar una materia, siguiendo una "forma" que es el Logos, sino que creó, ad arbitrium suum, ex voluntate et potestate, ad auctorem Deum exprimendum ${ }^{153}$. Teme, pues, presentar al Logos como principio formal, sospechando algún linaje de necesidad, y así opta por presentarlo como principio ejecutivo ${ }^{154}$. Hay, sin duda, en Ambrosio gran variedad y ambigüedad, en los modos de presentar la imagen, por sus fuentes de las que

149. De Trinit. VIII, 48-52, PL. 10, 271-274; Ibid. XI, 5, PL. 10, 402.

150 C. Consitantium, 21, PL. 10, 596 s. Imago est rei ad rem coaequandique imaginata et indiscreta similitudo... Qud imago est, ut rei imago sit, spieciem necesse est et naturam et esissentiam, secundum quad imago est, in sie habeat auctoris (De Synodis, 13, PL. 10, 490; Dle Trinit. 11, 5, PL. 10, 402 Ibid. VIII, 47, PL. 10, 271).

151 In Ps. 118, X, 7, PL. 9, 566. El argumento, sin embargo, es de doble filo, ya que también se puede argumentar: ya que consta que el hombre es imagen die Dios, ha de tener la misma naturaleza que su Dios. Y en ese sentido vale para el ordien sobrenatural.

152 Consummatur itaque homo imago Dei... secundum dispoisitam primi hominis figurationem... agnoscens Deum suum, ac per id imago ejus (De Trinit. 11, 49, PL. 10, 432).

153 S. Ambrosio, Exameron, I, 1 s., PL. 14, 123; Ibid. 5 y 7, PL. 14, 124 s. 154 Hexam. III, 7, 32, PL. 14, 169. 
depende. La falta de distinción entre la imagen y la semejanza crea confusión, ya que entiende la imagen como semejanza moral y sobrenatural : virtutum gratia renitens splendorque pietatis ${ }^{155}$. También el carácter práctico de Ambrosio crea confusión, ya que identifica la contemplación con la religión, el conocimiento con la experiencia religiosa, al estilo de los gnósticos. La sabiduría especulativa es calificada de petulancia y curiosidad ${ }^{156}$.

La imagen de Dios es el Hijo ${ }^{157}$. El hombre es sólo imagen de la imagen. Ambrosio conoce el argumento apologético, apoyado en el cuerpo humano, y ha servido de fuente para muchos escritos posteriores ${ }^{158}$. Pero no pone la imagen en el cuerpo, ni en el hombre entero, sino sólo en el alma ${ }^{15 \%}$. Rehuye entrar en la discusión del texto Gen. 1, 26 ss. y se contenta con una postura un tanto ambigua ${ }^{160}$, distinguiendo un "hombre de vanidad" que es el pecador, y un "praestantior homo" que sin duda es el justo:

Un corresponsal, Horontiano se asombra de que Ambrosio, al explicar el Hexámeron, se calle precisamente cuando se trata del hombre, como si rehuyese el problema. Esta ocasión le obliga a afrontar el problema ${ }^{161}$. La imagen sería doble, natural y sobrenatural, en cuanto que la naturaleza racional nos asemeja a Dios y la razón se nos dio para la santificación ${ }^{162}$. Pero a esas imágenes fundamentales habría que añadir otras semejanzas menores: el dominio sobre la tierrả para su comodidad y regalo, el conocimiento de los secretos celestiales, en lo cual se asemeja también el hombre a Dios ${ }^{163}$. Finalmente, hay que añadir la justicia, el complejo de todas las virtudes ${ }^{164}$. De ese modo obtenemos una de las más bonitas descripciones del hombre, hecho a imagen de Dios ${ }^{165}$. Es un canto digno

155 Hexam. VI, 7, 40 s., PL. 14, 257.

156 De Jacob et Beata vita, 1 y 8, PL. 14, 597 y 611; De Job et David, I, 9, 29, PL. 14, 809; In Lc. Pról., PL. 15, 15, 30.

157 Hexam. I, 18 s., PL. 14, 131.

158 Ibid. VI, 9, 54 ss., PL. 14, 264 ss.

159. In hoc paradiso hominem Deus posuit... non eum hominem, qui secundum imaginem Diei est, sed eum qui secundum corpus (De Paradiso, 1, 5, PL. 14, 276).

160 De Isaac et anima, 2, 4 s., PL. 14, 504 s. Apostolus dicit imaginem Patris Christum esse... Cur imago, si similitudinem non habet?... Imago docet non esse dissimilem, character expressum esse significat, splendor sugnat aetiernum. Imago utique... simplex de Deo, egressa de patre, expressa de fonte... Imago ista veritas est, jutitia, virtus... Pater Filio dicit: ad imagimem et similitudinem nostram (De fide, 7, 48-52, PL. 16, 359 s.). Cfr. Ep. 43, 1, PL. 16, 1.129.

161 Ep. 43, 1 s., PL. 16, 1.129.

162 Quod hominem Deus fecit consomtem naturae (II Pet. 1, 4). Undie non inmerito quidam ait: cujus et genus, sumus (Act. 17, 28); dedit enim nobis die cognatione sua, et rationabilis scilicet waturaie, ut qugeramus illud divinum... (Ibid. 10, PL. 16, 1.132).

163 Ibid. 11, PL. 16, 1.132.

164 Ibid. 12, PL. 16, 1.132.

165 Homo, specie gratus, mente sublimis; ut omni esset creaturase miraculo. In quo ad similitudinem aeterni Dei noûs lesset invisibilis, humana specie amictus. Hic est nôेs, animae vigor, principatum animae et corporis sibi quasi rector 
de los coros de Sófocles, dentro del estilo grandilocuente de los estoicos: el vigor intelectual con que el hombre domina en el mundo, descubre lo que está oculto y distante, vence a los animales que parecen mucho más fuertes, infundiéndoles respeto y temor, todo eso está demostrando que el hombre es imagen de Dios, representa en la tierra al Dios del cielo. Estas amplificaciones oratorias, de inspiración filosófica, no impiden el considerar la imagen como una cualidad sobrenatural, siempre que se trata del punto de vista cristiano: se perdió con el pecado de Adán y consiste en la semejanza moral con el Hijo de Dios, con Jesucristo ${ }^{166}$. La lucha contra los arrianos ha fijado ya definitivamente el sentido de la imagen. El problema no es ya el hombre como tal sea o no sea imagen de Dios: el texto Gen. 2, 7 se utiliza ahora para demostrar la divinidad de Cristo, la consustancialidad del Verbo con el Padre, puesto que el Padre dice al Hijo: "hagamos al hombre a nuestra imagen y semejanza". Las necesidades de la polémica abren una nueva perspectiva, pero nos desvían de la Biblia, del concepto que los semitas tenían del hombre como Imagen de Dios, o de la teoría paulina de la imagen de Dios, menoscabada por el pecado original y abrillantada por la redención.

En conclusión, podríamos decir que el texto Gen. 2, 7, quedaba ya agotado en sus posibles interpretaciones: su ciclo se había ya cerrado. Era demasiado aventurado presentar una nueva interpretación o escoger una de tantas como la historia ofrecía. Tanta variedad terminaba por desvirtuar todas las interpretaciones, dejándolas todas en calidad de posibles, pero sin certidumbre tradicional. Fue San Agustín quien, al abrir nuevos horizontes, volvió a plantear el problema antiguo. La "imagen natural" de Dios volvió a convertirse en problema agudo para un hombre cuyo ideal máximo consistía en saber a qué atenerse sobre la relación fundamental del hombre con Dios: Deum et animan scire cupio, nibil amplius 167.

\section{P. Lope Cilleruelo, O. S. A.}

\footnotetext{
vindicans. Quem etiamsi non vídent animailia caeteral, tamen reformidant; sicut nos D'eum, quem non vidlemus, timemus; et eo pilus meituimus, guidi non vidiemus... Ita noûs hominis videt omnia et non videtur... ad similitudinem Dei summi quem imitatur et sequitur, cujus imago pro exiguis portionibus in singulis figuratur... (Ibid. 14, PL. 16, $1.133 \mathrm{s.}$.).

${ }_{166}$ Nisi per imaginem Dei, ad imalginem Dei esse non possis (Ibid. I, 7, 53, PL. 16, 540; Ibid. I, 17, 111, PL. 16, 554; Die Incarnationis Domini Sacram, 10, 107-112, PL. 16, 844 s.; Serm. c. Auxentium, 32, PL. 16, 1.017).

167 S. Agustín, Soliloquios, I, 2, 7, PL. 32, 872.
} 